\title{
Evolution of North Himalayan gneiss domes: structural and metamorphic studies in Mabja Dome, southern Tibet
}

\author{
Jeffrey Lee ${ }^{\mathrm{a}, *}$, Bradley Hacker ${ }^{\mathrm{b}}$, Yu Wang ${ }^{\mathrm{c}}$ \\ a Department of Geological Sciences, Central Washington University, Ellensburg, WA 98926, USA \\ ${ }^{\mathrm{b}}$ Department of Geological Sciences, University of California, Santa Barbara, CA 93106, USA \\ ${ }^{\mathrm{c}}$ Department of Geology, China University of Geosciences, Beijing, 100083 China
}

Received 10 February 2003; received in revised form 9 December 2003; accepted 24 February 2004

\begin{abstract}
Field, structural, and metamorphic petrology investigations of Mabja gneiss dome, southern Tibet, suggest that contractional, extensional, and diapiric processes contributed to the structural evolution and formation of the domal geometry. The dome is cored by migmatites overlain by sillimanite-zone metasedimentary rocks and orthogneiss; metamorphic grade diminishes upsection and is defined by a series of concentric isograds. Evidence for three major deformational events, two older penetrative contractional and extensional events and a younger doming event, is preserved. Metamorphism, migmitization, and emplacement of a leucocratic dike swarm were syntectonic with the extensional event at mid-crustal levels. Metamorphic temperatures and pressures range from $\sim 500{ }^{\circ} \mathrm{C}$ and $\sim 150-450 \mathrm{MPa}$ in chloritoid-zone rocks to $705 \pm 65^{\circ} \mathrm{C}$ and $820 \pm 100 \mathrm{MPa}$ in sillimanite-zone rocks. We suggest that adiabatic decompression during extensional collapse contributed to development of migmatites. Diapiric rise of low density migmatites was the driving force, at least in part, for the development of the domal geometry. The structural and metamorphic histories documented in Mabja Dome are similar to Kangmar Dome, suggesting widespread occurrence of these events throughout southern Tibet.
\end{abstract}

(C) 2004 Elsevier Ltd. All rights reserved.

Keywords: Gneiss domes; Deformation; Extension; Contraction; Diapirism; Metamorphism; Tibet

\section{Introduction}

Gneiss domes in orogenic belts worldwide are typically composed of a core of granitic migmatites or gneisses structurally overlain by a mantle or cover of high-grade metasedimentary rocks (e.g. Eskola, 1949). A number of mechanisms have been proposed for the origin of gneiss domes, ranging from diapirism driven by buoyancy and low viscosity of hot, low-density middle crustal rocks or lowdensity magma (e.g. Ramberg, 1980; Calvert et al., 1999; Teyssier and Whitney, 2002), extensional exhumation of middle crustal rocks in the footwalls of low-angle normal faults (e.g. Brun and Van Den Driessche, 1994; Escuder Viruete et al., 1994; Holm and Lux, 1996), and contractional exhumation of middle crustal rocks via thrust duplexing and rapid surface erosion (e.g. Brun, 1983; Burg et al., 1984), to some combination of these processes (e.g. Lee et al., 2000).

\footnotetext{
* Corresponding author. Tel.: + 1-509-963-2801; fax: + 1-509-963-2821.

E-mail address: jeff@geology.cwu.edu (J. Lee).
}

Each of these mechanisms, or combinations thereof, have significantly different implications for the tectonic evolution of an orogen.

Each mechanism also makes dramatically different geometric, kinematic, petrologic, and timing predictions related to: (a) the nature of the contact between the carapace of metasedimentary rocks and gneissic core, (b) the threedimensional structural and kinematic history of the high grade rocks and overlying lower grade rocks, (c) the temporal, spatial, and genetic relations among metamorphism, magmatism, and deformation, and (d) the timing and rates of cooling within the domes. Structural and map criteria used to identify diapirs in areas without regional deformation include plutons and/or migmatites in the center or core of the dome; a foliation that is conformable to the core-cover contact, concentric, and possessing a dome-up sense of shear; radial and tangential lineation patterns; strain that increases toward the contact; and syn- to post-kinematic growth of metamorphic porphyroblasts in the cover rocks (e.g. Schwerdtner et al., 1978; Brun and Pons, 1981; 
Coward, 1981; Dixon and Summers, 1983; Bateman, 1984; Van Den Eeckhout et al., 1986; Jelsma et al., 1993). Additional criteria may include a core-cover contact characterized by intrusion of the core into the cover, a steep metamorphic field gradient in cover rocks, and a cooling history that is symmetrical across the dome (e.g. Calvert et al., 1999).

Extensional exhumation similar to that experienced by the metamorphic core complexes of the western United States of America (e.g. Crittenden et al., 1980) has also been proposed as a mechanism for gneiss dome formation. Such gneiss domes are characterized by a fault contact between the core and cover that omits structural and metamorphic section, gneissic rocks in the footwall that originated at higher temperatures and greater depths compared with mantling rocks in the hanging wall, a dominant foliation in the core that may or may not be parallel to the fault, and strain in the footwall that increases toward the core-cover contact (e.g. Lee et al., 1987; Reynolds and Lister, 1990; Hurlow et al., 1991; Lewis et al., 1999). Footwall lineations are unidirectional, the shear sense is normal, down-dip, and the cooling history is asymmetric with ages decreasing down-dip (e.g. Davis et al., 1986; Lee et al., 1987; McGrew and Snee, 1994; Lee, 1995). Finally, there is a geometric and kinematic relationship between deformational fabrics in the core rocks and the lower grade cover or hanging wall rocks: brittle normal faults in the hanging wall yield the same direction of extension as the footwall (e.g. Miller et al., 1983; Wernicke, 1985).

Gneiss domes formed by contraction fall into three categories. Domes formed by the development of thrust duplexes are characterized by a fault contact between the core and cover that duplicates structural and metamorphic section, and hanging wall rocks that originated at higher temperatures and greater depths compared with footwall rocks (e.g. Burg et al., 1984). The foliation in the core may or may not be parallel to the fault and strain typically increases toward the contact. Lineations are unidirectional, shear sense is reverse, up-dip, and the cooling history is asymmetric with ages increasing up-dip. In contrast, domes formed by horizontal contraction, without shear, of gneissic rocks overlain by metasedimentary rocks, contain a foliation perpendicular to the core-cover contact (Brun, 1983); domes defined by interference folds indicate formation by superposed folding (e.g. van Staal and Williams, 1983).

Finally, gneiss dome formation may be the result of some combination of these end-member processes (e.g. Lee et al., 2000; Brown et al., 2002; Teyssier and Whitney, 2002). For example, Teyssier and Whitney (2002) postulated that buoyancy of partially molten crust, coupled with extension and/or erosion, results in a domal geometry cored by highgrade rocks.

The North Himalayan gneiss domes, southern Tibet are a series of isolated gneiss domes exposed within the Tethyan Himalaya south of the Indus-Tsangpo Suture zone and north of the Southern Tibetan detachment system (Fig. 1). A variety of mechanisms have been proposed to explain the formation of these gneiss domes, thereby implying different roles in Himalayan tectonics. Le Fort and co-workers (Le Fort, 1986; Le Fort et al., 1987) suggested that anatectic melts buoyantly rose during contraction to create the domal form. In contrast, Burg et al. (1984) argued that Kangmar Dome, the best known North Himalayan gneiss dome (Fig. 1), formed from purely contractional deformation by a thrust duplex at depth. Based on reconnaissance studies, Chen et al. (1990) concluded the opposite-that Kangmar Dome formed by processes similar to those associated with metamorphic core complexes of the western United States of America; and, that like the Southern Tibetan detachment system, Kangmar Dome is an extensional feature that formed in response to gravitational collapse of the Himalayan topographic front. Lee et al. (2000) completed detailed structural, metamorphic petrology, and thermochronology studies, and, building upon the investigations of Burg et al. (1984) and Chen et al. (1990), proposed that middle crustal extension followed by south-directed thrusting led to the high strain penetrative fabrics and domal geometry. They also suggested that extensional fabrics within Kangmar Dome were the result of gravitational collapse of overthickened crust and speculated that increased friction along the Main Himalayan Thrust beneath Kangmar Dome region caused the change from extension to contraction (e.g. Dahlen, 1990).

These studies implied that the mechanism of gneissdome formation inferred for Kangmar Dome was regional in nature and applied to much of southern Tibet. To test the different models for gneiss dome formation and whether the processes of gneiss dome evolution in southern Tibet are indeed regional in nature, this paper presents the results of new detailed geologic mapping, structural, kinematic, and quantitative thermobarometric investigations in Mabja Dome, southern Tibet, an area that has not been previously studied in such detail. Our new investigations show that formation of structural and metamorphic fabrics and the domal geometry in Mabja Dome resulted from a combination of contractional, extensional, and diapiric mechanisms.

\section{Regional setting}

The North Himalayan gneiss domes are exposed within the Tethyan Himalaya, approximately halfway between the Indus-Tsangpo Suture zone to the north and the Southern Tibetan detachment system to the south (Fig. 1). This region is underlain by a Cambrian to Eocene miogeosynclinal sedimentary sequence deposited on the passive northern margin of the Indian continent (Gansser, 1964; Le Fort, 1975). The Tethyan Himalaya is structurally complex, exhibiting Cretaceous to Quaternary reverse faults and folds (e.g. Le Fort, 1975; Searle, 1983; Burg and Chen, 1984; Ratschbacher et al., 1994; Quidelleur et al., 1997; Searle 


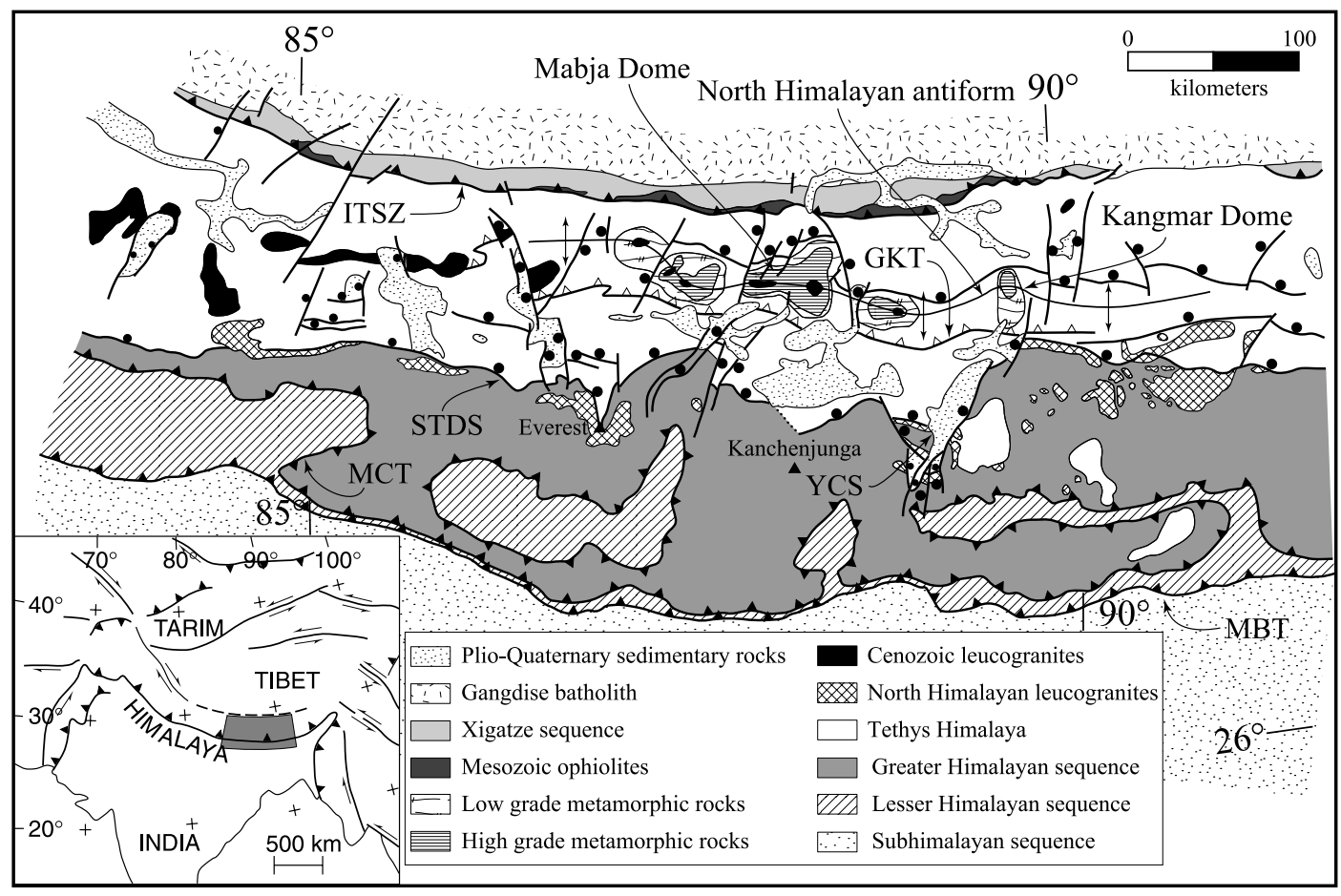

Fig. 1. Regional tectonic map of the central Himalaya orogen after Burchfiel et al. (1992) and Burg et al. (1984) showing the location of Mabja Dome. GKT; Gyirong-Kangmar thrust fault system; ITSZ, Indus-Tsangpo suture zone; MBT, Main Boundary Thrust; MCT, Main Central Thrust; STDS, Southern Tibetan Detachment System; YCS; Yadong cross-structure; thrust fault, teeth on the hanging wall; normal fault, solid circle on the hanging wall. Inset shows location of regional tectonic map; modified from Burchfiel et al. (1992) and Tapponnier et al. (1982).

et al., 1997; Yin et al., 1994, 1999) and extensional structures (e.g. Molnar and Tapponnier, 1975; Armijo et al., 1986; Mercier et al., 1987; Ratschbacher et al., 1994) in a variety of orientations.

Mabja Dome, north of Kanchenjunga (Fig. 1), is the largest of the North Himalayan gneiss domes, all of which define the North Himalayan antiform and lie in the hanging wall of the north-dipping Gyirong-Kangmar thrust fault system. Previous work within Mabja Dome is restricted to cursory geochronologic and thermochronologic studies. Two different varieties of slightly deformed two-mica granites exposed west of the core of the dome (Maluski et al., 1988) yielded monazite $\mathrm{U} / \mathrm{Pb}$ ages of $9.2 \pm 0.9$ and $9.8 \pm 0.7 \mathrm{Ma}$ (Scharer et al., 1986). ${ }^{40} \mathrm{Ar} /{ }^{39} \mathrm{Ar}$ thermochronology on biotite and muscovite from both the granitic rocks and orthogneisses yielded disturbed spectra with total gas ages of 6-8 Ma (Maluski et al., 1988). The locations of these samples were not reported.

\section{Geology of Mabja Dome}

\subsection{Gneissic and sedimentary rocks}

Mabja Dome has a core of migmatitic orthogneiss mantled by Paleozoic orthogneiss and metasedimentary rocks, which are in turn overlain by Triassic and Jurassic metasedimentary and sedimentary rocks that range from sillimanite zone at the base to unmetamorphosed at the top (Figs. 2-4); age assignments for metasedimentary and sedimentary units follow those of the Regional Geological Surveying Party (1993). At the base of the section is the Paleozoic(?) K-feldspar augen $(\leq 5 \mathrm{~cm})+$ biotite + plagioclase + quartz \pm muscovite \pm sillimanite \pm garnetbearing granitic migmatitic orthogneiss, og; local pockets and layers or segregation banding of leucosomes and melanosomes suggest partial melting. The top of the basal orthogneiss is an intrusive contact that abruptly interfingers with overlying metapelite. An S2 foliation within the orthogneiss includes swirly, leucosomal segregations that are locally folded and boudinaged; leucosomes occur in boudin necks, suggesting melting syntectonic with foliation formation (e.g. Brown, 1994; Nyman et al., 1995). A poorly developed stretching lineation and well-developed strain shadows on K-feldspar augen exposed on XZ and $\mathrm{YZ}$ sections suggest oblate strain at these structural depths.

Structurally overlying og is a moderately well-exposed 'Paleozoic orthogneiss and paragneiss' complex, Pop, composed of dominantly K-feldspar ( $\leq 3 \mathrm{~cm}$ across) granitic augengneiss with numerous pendants of metasedimentary pelite (Figs. 2-4). The orthogneiss appears to be a sheet-like body with a granitic top and more mafic (biotite granodiorite) base. The upper contact with overlying metapelites is sharp, although aplite veins and dikes feed into the overlying quartzite and the orthogneiss becomes finer grained toward the contact. These observations suggest 


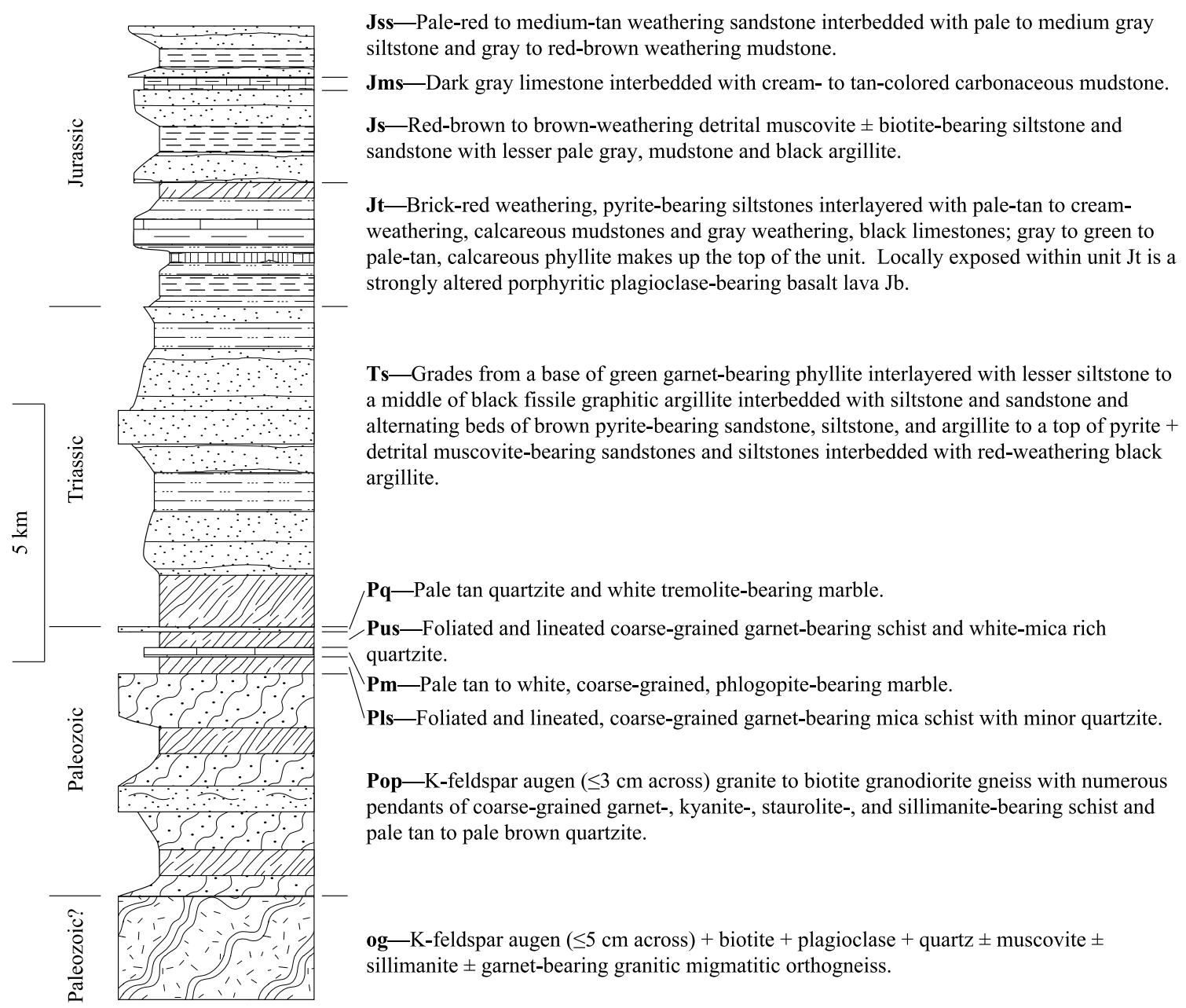

Fig. 2. Stratigraphic section of pre-Quaternary rocks exposed in Mabja Dome. Relative thicknesses are shown.

that the upper contact is intrusive; the lower contact is not exposed. The orthogneiss possesses a strong S2 foliation defined by aligned micas, weakly to strongly flattened quartz grains, and mica and quartz segregations, and a welldeveloped stretching lineation, defined by smeared biotite, ribbon quartz grains, and strain shadows on K-feldspar augen (Fig. 5a), indicating approximately plane strain. The schists range from garnet zone at the top, through kyanite and staurolite zones in the middle, to sillimanite zone at the base (Fig. 6). Schist horizons contain a well-developed L-S fabric, also indicating approximately plane strain. The S2 foliation is defined by aligned micas, weakly to strongly flattened quartz grains, and mica and quartz segregations; the lineation is primarily defined by aligned micas and porphyroblast strain shadows composed of quartz, biotite, white mica, and plagioclase. One orthogneiss sample, from the top of unit Pop, yielded a preliminary discordant multigrain and single-grain zircon $\mathrm{U} / \mathrm{Pb}$ analyses suggesting early Paleozoic crystallization (Lee et al., 2004).
Structurally above Pop is a sequence of Paleozoic schist, marble, and quartzite, which contain well-developed foliation and stretching lineation (Figs. 2-4). This sequence grades depositionally upward into an overlying, areally extensive sequence of Triassic siliciclastic rocks, unit Ts. Metamorphic grade within unit Ts decreases upsection from garnet zone at the base to unmetamorphosed sandstone, siltstone, and argillite at the top. Unit Ts is in a gradational contact with an overlying sequence of dominantly siliciclastic rocks with lesser limestone of Jurassic age.

\subsection{Intrusive rocks}

The orthogneiss and metasedimentary rocks have been intruded by deformed amphibolite dikes, a variably deformed pegmatite and aplite dike swarm, two undeformed biotite + muscovite granites, and an undeformed rhyolite porphyry dike. 


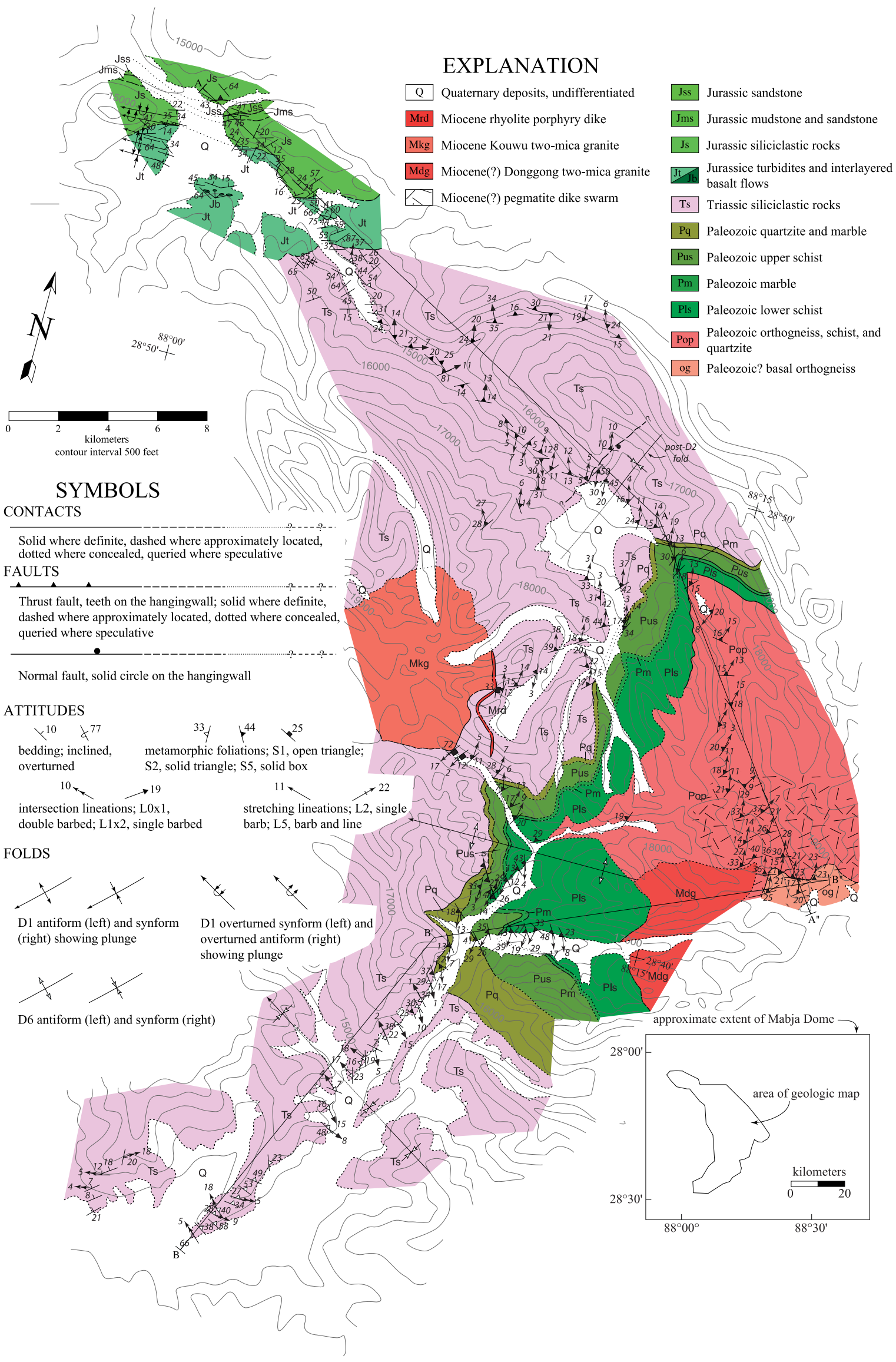


KEY

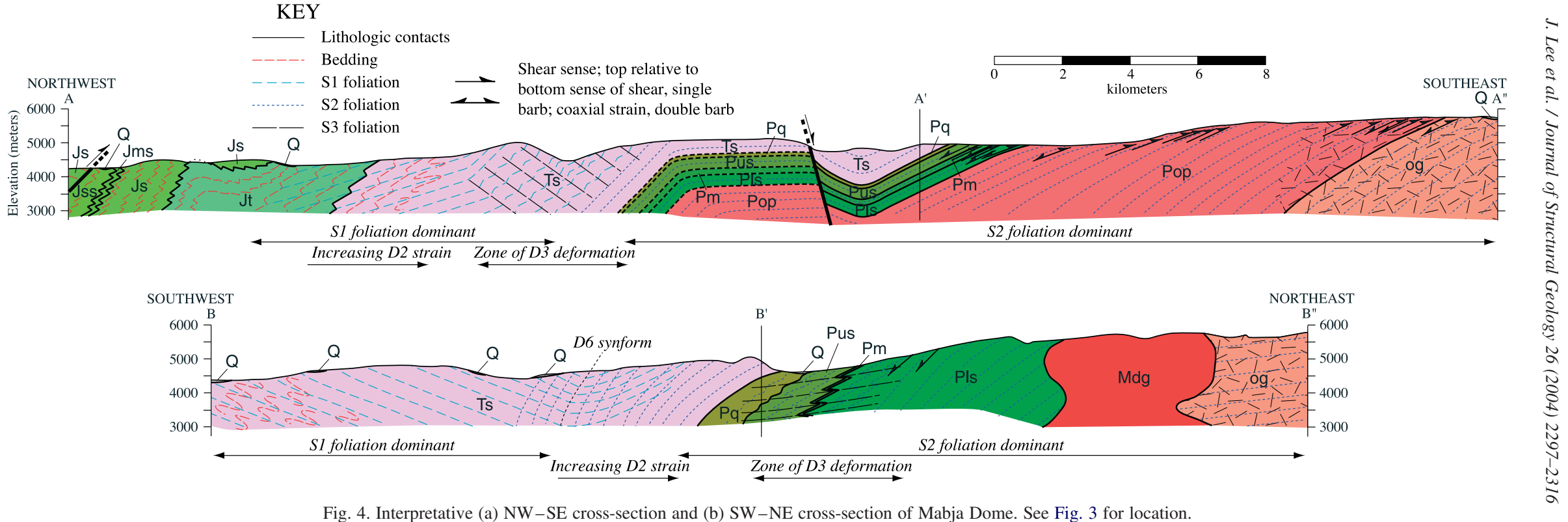

Fig. 4. Interpretative (a) NW-SE cross-section and (b) SW-NE cross-section of Mabja Dome. See Fig. 3 for location. 

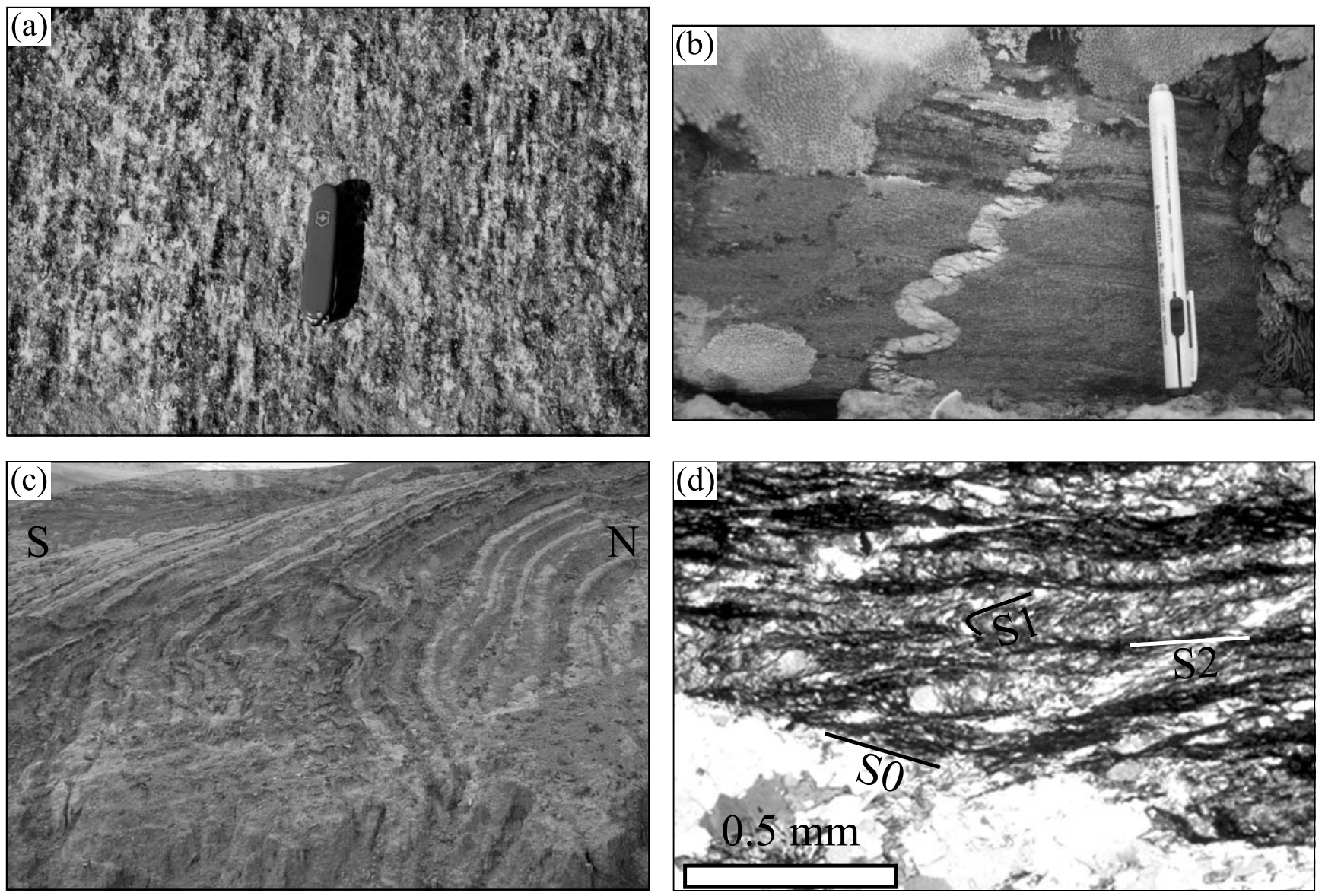

Fig. 5. (a) Field photo showing well-developed stretching lineation, here defined primarily by smeared biotite and ribbon quartz grains, within Pop orthogneiss. (b) Field photo showing aplite dike tightly folded with an axial planar surface parallel to the S2 mylonitic foliation developed within a granodiorite orthogneiss. View to west approximately perpendicular to the S2 foliation and approximately parallel to stretching lineation. (c) Field photo showing disharmonic, S-vergent F1 folds of bedding within unit Jt. (d) Photomicrograph of portion of a limb from a $\sim 3 \mathrm{~cm}$ wavelength isoclinal D2 fold of bedding (S0) with an axial planar S2 cleavage that crenulates the S1 foliation. Sample from a phyllite in unit Ts; photomicrograph is cross nicols; section cut perpendicular to the L0x2 intersection lineation and the S2 foliation.

Local, penetratively deformed, decimeter-wide amphibolite dikes of unknown age, consisting of hornblende + plagioclase \pm epidote \pm quartz \pm biotite \pm garnet, are interlayered with schist and orthogneiss of unit Pop. A coarse- to medium-grained porphyritic to equigranular muscovite $+\mathrm{K}$-feldspar + quartz \pm biotite \pm garnet-bearing pegmatite and fine-grained leucocratic aplite dike swarm comprises as much as $30-35 \%$ of the lower half of Pop and unit og; this swarm first appears within the kyanite zone, and dramatically increases in volume downward toward the sillimanite zone (Figs. 3 and 4). Locally, at the deepest structural levels within unit og, pegmatites exhibit cores of quartz $+\mathrm{K}$-feldspar and rinds of nearly 100\% biotite, suggesting segregation and partial melting. The leucocratic dike swarm shows a range of field relations with respect to D2 fabrics-concordant to the S2 mylonitic foliation, boudinaged within the foliation, folded with the axial planar surface parallel to the S2 foliation (Fig. 5b), sheared within the foliation, and discordant to the foliation. We did not observe an obvious pervasive mesoscopic foliation within the dikes, although some dikes exhibit a foliation that feathers into their rims. Nevertheless, quartz grains exhibit a range of microfabrics indicating penetrative deformation, including a strong grain-shape foliation and ribbon grains. These meso- and microscopic relations indicate that emplacement of the dike swarm was syn- to late-tectonic with respect to development of the S2 mylonitic foliation.

Two medium- to coarse-grained, porphyritic two-mica granites, informally referred to as the Donggong and Kouwu granites, units Mdg and Mkg, respectively, were emplaced at deep structural levels into units Pls, Pop, and og, and at shallower structural levels into unit Ts, respectively (Figs. 3 and 4). We did not observe mesoscopic or microscopic evidence for penetrative deformation within either granite. Biotite-bearing granite dikes from the Donggong granite cut foliated and sheared pegmatite and aplite dike swarm and pegmatites from the Kouwu granite cut the S2 foliation in the surrounding metapelites. These field and microstructural observations indicate that the two granites were emplaced after D2 deformation. Unlike the Donggong granite, the Kouwu granite possesses well-developed $\sim 3$-km-wide 


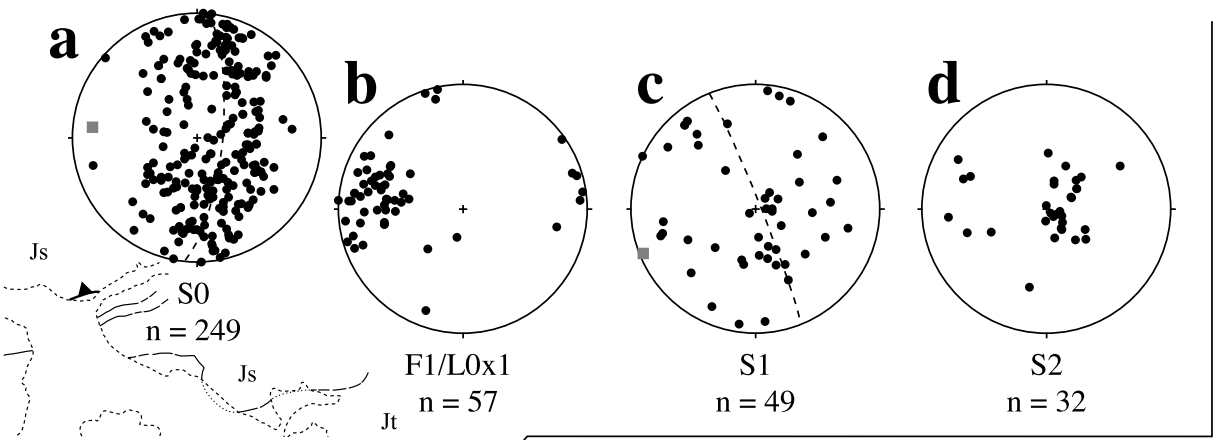

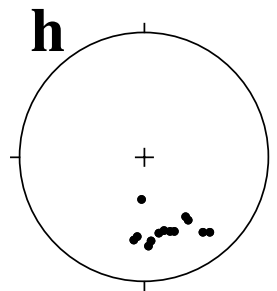

Shear bands $\mathrm{n}=13$

\section{Northern Domain}

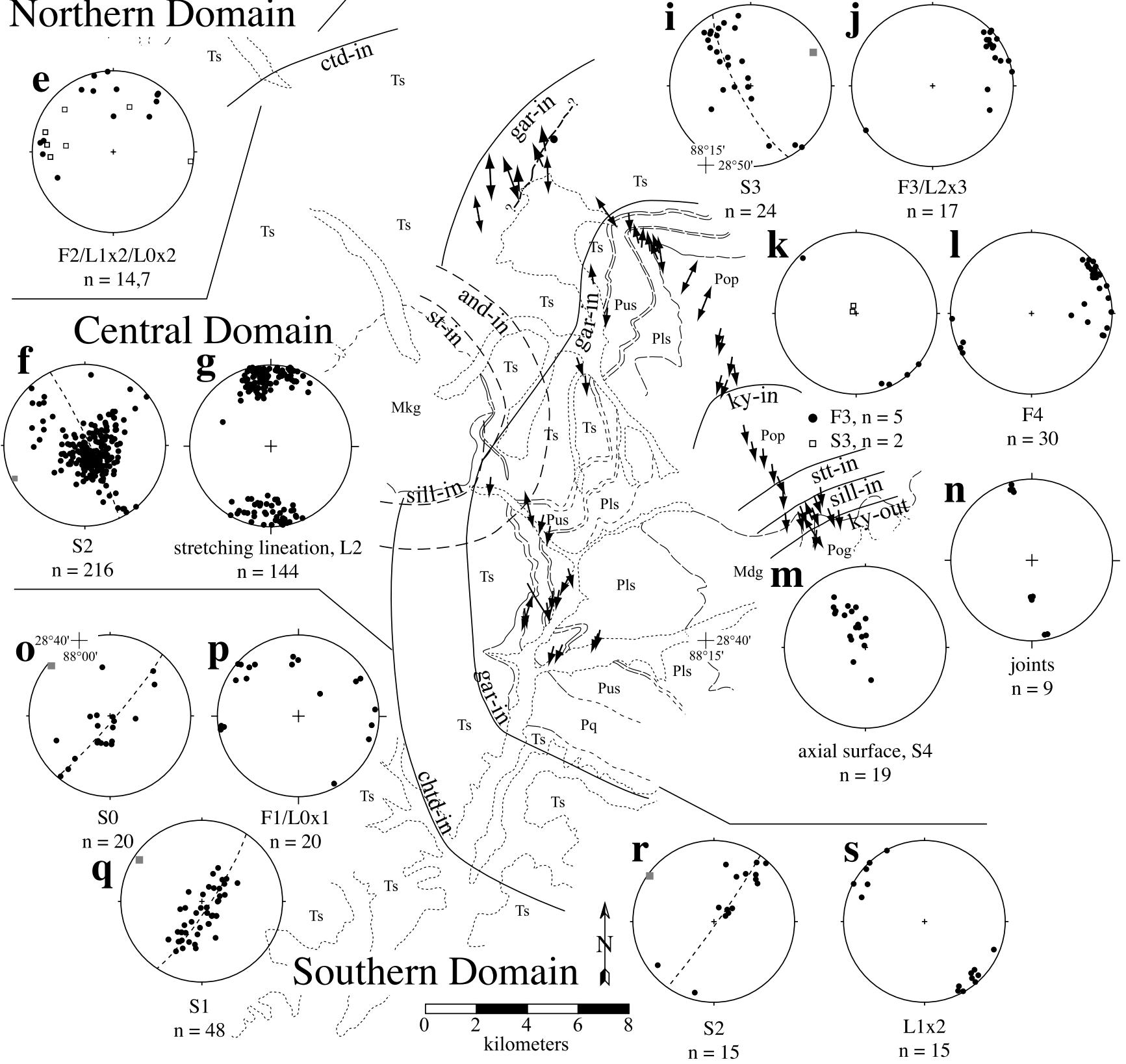

Fig. 6. Simplified geologic map of Mabja Dome showing structural domains, metamorphic isograds, and shear sense. Structural data plotted on lower hemisphere, equal area projections; number of measurements indicated. In the northern domain: (a) poles to bedding; (b) F1 fold axes and L0x1 intersection lineations; (c) poles to S1 foliation; (d) poles to S2 foliation; and (e) closed circles, F2 fold axes and L1x2 intersection lineations; open squares, L0x2 intersection lineations. In the central domain: (f) poles to S2 mylonitic foliation; (g) Ls2 stretching lineations; (h) poles to shear bands; (i) poles to S3 cleavage on the northwest flank of the dome; (j) F3 fold axes and L2x3 intersection lineations on the northwest flank of the dome; (k) F3 fold axes and poles to S3 cleavage on the southwest flank of the dome; (1) F4 fold axes; (m) poles to S4 axial surfaces; and (n) poles to joints. In the southern domain: (o) poles to 
contact metamorphic and $\sim 0.5-\mathrm{km}$-wide deformation aureoles (see S5 in Fig. 3) within the surrounding metapelites (Figs. 3 and 4). The pelites record increasing metamorphic grade, from andalusite zone to sillimanite zone, proximal to the granite. Andalusite porphyroblasts on the $\mathrm{S} 2$ foliation surface are randomly oriented and, in thin section, overgrow the S2 mylonitic foliation (Fig. 7d), indicating growth after D2 deformation. Zircon and monazite $\mathrm{U}-\mathrm{Pb}$ geochronology from the Kouwu granite yielded an emplacement age of 14.0-14.6 Ma (Lee et al., 2002, 2004). Finally, an undeformed rhyolite porphyry dike of unknown age was emplaced across unit Ts and along the contact between unit Ts and the Kouwu granite.

\section{Structural chronology}

\subsection{Introduction}

On the basis of mapping and structural studies at 1:50,000 scale in Mabja Dome, we have identified two major penetrative deformational events. A first deformational event, D1, horizontally shortened bedding into a series of asymmetric folds. A second, superimposed highstrain deformational event, D2, vertically thinned and horizontally stretched the lower part of the sequence. Data from these two deformational events define three structural domains: northern and southern domains at shallower structural levels, which are dominated by D1 structural fabrics, and a central, deeper domain, which contains highstrain D2 structural fabrics (Fig. 6). Microstructural textures indicate that peak metamorphism occurred during the D2 deformation. Superimposed on D2 fabrics are two lowstrain, low-temperature D3 and D4 fabrics, a moderatestrain, high-temperature D5 fabric related to the emplacement of the Kouwu granite, D6 doming, and brittle structures.

\subsection{D1 deformation}

The oldest event, D1, best exposed and dominant at highest structural levels, folded bedding into map- to mesoscopic scale, upright to inclined, open to tight, typically disharmonic F1 folds. At the highest structural levels in the northern domain, W-plunging, $\mathrm{N}$ - and S-vergent F1 folds (Figs. 3, 4, 5c and 6a and b) vary from kink folds, with wavelengths of decimeter scale, associated with gently to moderately $\mathrm{N}$ - and S-dipping axial surfaces, to mapscale folds with shallow NW- or SE-dipping axial surfaces (Fig. 6c). These axial surfaces do not possess a penetrative axial planar fabric. The presence of both $\mathrm{N}$ - and
S-vergent F1 folds suggests either a switch in shear or that these folds are parasitic to a larger fold. Mesoscopic to mapscale F1 folds are spectacularly exposed within unit Jt and the upper part of unit Ts, where the long limbs dip moderately $\mathrm{N}$ and the short limbs dip steeply S. Scarce, weakly developed quartz- and calcite-filled strain shadows on pyrite within unit $\mathrm{Jt}$ indicate a $\sim \mathrm{WNW}$-trending stretching lineation. With increasing structural depth, a weakly developed, S-dipping, spaced or pressure solution S1 cleavage develops as the axial planar surface to open, commonly disharmonic, N-vergent $\sim$ EW-trending folds with centimeter- to meter-scale wavelengths. At even greater depths the S1 fabric becomes a penetrative, finegrained slaty cleavage defined by mica, quartz, and graphite, and folds become progressively tighter until isoclinal and S0 has been transposed parallel to the $\mathrm{S} 1$ foliation.

In the southern domain, NW-trending F1 folds of bedding (Fig. 6o and p) are tight to isoclinal. The associated axial planar S1 foliation dips moderately NE or, where folded by a younger deformational event, SW (Fig. 6q). The $\mathrm{S} 1$ axial planar foliation is a fine-grained, typically graphitic slaty cleavage at the highest structural levels in unit Ts, but becomes coarser and more phyllitic at deeper structural levels in unit Ts where it is defined by aligned fine-grained micas, flattened detrital quartz grains, and microlithons rich in mica or quartz.

\subsection{D2 deformation}

A younger, high-strain deformational event, D2, is manifested at higher structural levels on the northwest flank of the dome as a generally moderately NNWdipping, closely spaced to weakly penetrative crenulation cleavage, S2, developed at high angles to S1 (Figs. 5d and $6 \mathrm{~d}$ ). F2 crenulation axes of either bedding or S1 trend EW or NS (Fig. 6e). With increasing depth, S2 changes from a spaced axial planar cleavage to open to tight folds of $\mathrm{S} 1$ to a penetrative axial planar cleavage to isoclinal folds of S1. On the SW flank of the dome the $\mathrm{S} 1$ foliation is crenulated by a moderately SW-dipping spaced S2 cleavage (Fig. 6r) defined by microlithons rich in mica or quartz. With increasing depth, the S2 cleavage becomes a fine-grained slaty cleavage defined by mica + quartz + graphite, and bedding and the $\mathrm{S} 1$ foliation are transposed toward parallelism with $\mathrm{S} 2$; here, F2 crenulation axes trend NW-SE (Fig. 6s). With increasing structural depth on both flanks of the dome, the fold geometry of S0 and S1 changes from open to tight to isoclinal recumbent, and folds are associated with a moderately dipping penetrative S2 axial planar cleavage. At structural levels below the garnet-in isograd within

bedding; (p) F1 fold axes and L0x1 intersection lineations; (q) poles to S1 foliation; (r) poles to S2 foliation; and (s) L1x2 intersection lineations. Dashed line and solid square in (a), (c), (f), (i), (o), (q) and (r) are a best fit girdle to planar data and calculated fold axis, respectively. ctd-in, chloritoid-in isograd; gar-in, garnet-in isograd; ky-in, kyanite-in isograd; stt-in, staurolite-in isograd; sill-in, sillimanite-in isograd; ky-out, kyanite-out isograd; single arrows indicate top relative to bottom sense of shear; double arrows indicate coaxial strain. 

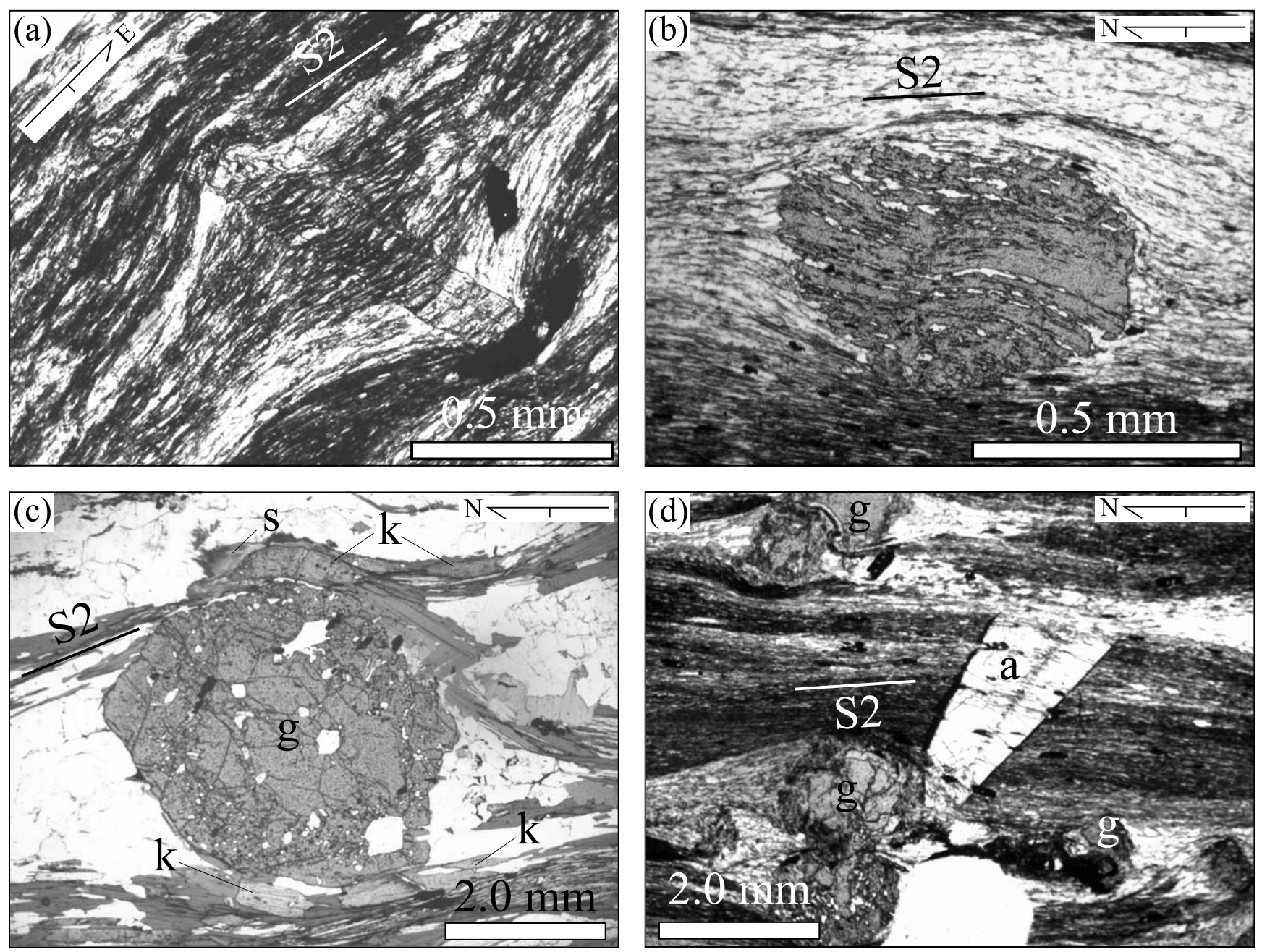

Fig. 7. Photomicrographs of schist units showing microstructural relations between metamorphic porphyroblasts and foliation. (a) Photomicrograph of a deformed Ts schist shows a chloritoid porphyroblast (center) with an internal inclusion trail, defined by quartz and micas, which is continuous with the external foliation, S2; the S2 foliation also tapers on either side of the porphyroblast. These observations indicate chloritoid growth was syntectonic with D2 deformation. (b) Strongly deformed Pus schist showing a large garnet porphyroblast (center) with an internal foliation of quartz, micas, and Fe-oxides, which is continuous with the external S2 foliation, indicating syntectonic growth. (c) Strongly deformed Pop schist showing a garnet porphyroblast (center) with the S2 foliation, defined by mica, quartz, kyanite, and sillimanite, wrapping around the garnet leading to development of strain shadows. Here, garnet growth predated formation of the S2 foliation. g, garnet; k, kyanite; s, sillimanite. (d) Strongly deformed Ts schist adjacent to the Kouwu granite showing an andalusite (center) that cuts across the S2 foliation indicating that it grew after formation of the foliation. a, andalusite; g, garnet. Photomicrographs are plane light; geographic orientation indicated. (a) is from a section cut perpendicular to the Ls2 stretching lineation and the S2 foliation and (b) - (d) are from sections cut parallel to the Ls2 stretching lineation and perpendicular to the S2 foliation.

the central domain, bedding and the S1 foliation have been transposed parallel to a mylonitic S2 foliation. The S2 mylonitic foliation dips moderately $\mathrm{NW}$ on the northwest flank of the dome and moderately SW on the southwest flank of the dome (Figs. 3, 4 and 6f). Associated with the high-strain $\mathrm{S} 2$ foliation is a $\sim \mathrm{N}-\mathrm{S}$ stretching lineation, Ls2 (Figs. 5a and 6g), defined by porphyroblast strain shadows, aligned biotite and muscovite aggregates, aligned kyanite and hornblende, quartz rods, K-feldspar ribbons and aggregates, and recrystallized tails on K-feldspar porphyroclasts. Uncommon preservation of the $\mathrm{S} 1$ foliation occurs within strain shadows where the S2 crenulation foliation is weak.

Kinematic indicators. Meso- and microscopic structures within orthogneiss and metasedimentary rocks, such as strain shadows on porphyroblasts, tails on K-feldspar porphyroclasts, oblique quartz grain-shape foliations, shear bands, asymmetric boudins of quartz veins, and small (centimeter-scale) normal faults record the sense of shear associated with and after the development of the high strain S2 foliation. Strain shadows on porphyroblasts consisting of quartz, white mica, biotite, and plagioclase are typically symmetrical, and locally asymmetrical. Oblique quartz grain-shape foliations are scarce because most quartz grains are polygonal. Shear bands, defined by drag of the $\mathrm{S} 2$ foliation, dip $\sim 35^{\circ}$ more steeply than the $\mathrm{S} 2$ foliation (cf. Fig. $6 f$ and h). Small normal faults dip $\sim 50-$ $60^{\circ}$ more steeply than the mylonitic S2 foliation, are 
typically spaced $1-5 \mathrm{~cm}$ apart; they offset the $\mathrm{S} 2$ foliation and shear bands as much as $2 \mathrm{~cm}$, indicating post $\mathrm{S} 2$ slip.

The prevalence of symmetric fabrics associated with the development of strain shadows implies that coaxial strain was dominant during the main, high temperature phase of D2 deformation. Lower temperature, late phase, D2 kinematic fabrics indicate a change from a nearly equal mix of top-down-to-the-N sense of shear and symmetric fabrics in the upper part of the garnet zone (unit Pop) on the north flank of the dome, to nearly exclusively top-down-tothe-S sense of shear at deeper structural levels on the north flank and along the southern flank of the dome (Figs. 4 and $6)$. The transition from a mix of shear sense indicators to dominantly top-S sense of shear does not occur at the geometric apex of the dome, but rather on the NW-dipping flank of the dome. Although we could not quantify the magnitude of shear strain, the bulk shear strain history appears to be dominantly coaxial during the high temperature, main phase of D2 to dominantly top-S sense of shear during the low temperature, late phase of D2.

\subsection{D3 deformation}

D3 fabrics are restricted to $\sim 4.5$-km-wide zones on both the northwest and southwest flanks of the dome (Fig. 4a and b). On the northwest flank, the S3 foliation is a weakly to moderately well developed SE-dipping, high-angle to perpendicular, spaced crenulation of S2; it defines small crenulations to tight mesoscopic folds and is restricted to a zone within unit Ts (Figs. 3, 4 and 6i). The S3 axial planar crenulation is more widely spaced $(50-100 \mathrm{~cm})$ on the subhorizontal limbs and more closely spaced (millimeter) on the subvertical limbs of F4 folds (see below) suggesting that D3 and D4 fabrics may be genetically related. F3 folds are commonly NW-vergent, have NE-trending axes (Fig. 6j) and, locally, are cut by discrete slip surfaces that are parallel to $\mathrm{S} 2$; sense of slip is top-N.

On the southwest flank, D3 fabrics are restricted to a zone straddling units $\mathrm{Pq}$ through Pus, and are characterized by SW-vergent, NW-trending, tight folds of S2 with wavelengths of decimeter to tens of meter scale (Figs. 3, 4 and 6k). Axial surfaces are subhorizontal, but are not associated with a penetrative axial planar foliation. S3 cleavages have been folded about NE-trending F4 fold axes. D3 structures on both flanks of the dome are consistently overturned down the present dip of the gneiss dome and disappear downsection as the S2 foliation becomes more flaggy and mylonitic.

\subsection{D4 deformation}

Locally within unit $\mathrm{Ts}$ on the northwest flank of the dome, S2 and S3 surfaces are folded into open to tight, NEtrending, NW-vergent, mesoscopic F4 folds (Fig. 61) with centimeter-to-decimeter wavelengths; often these folds are disharmonic. These folds possess a gently SE-dipping S4 axial surface (Fig. 6m) that is not associated with a penetrative axial planar foliation. Like D3 structures, D4 structures die-out downsection as the $\mathrm{S} 2$ foliation becomes more flaggy and mylonitic.

\subsection{D5 deformation}

A $\sim 0.5-\mathrm{km}$-wide deformational aureole, defined by a weakly developed penetrative foliation and lineation, is preserved around the Kouwu granite (Fig. 3). Locally, the foliation is axial planar to tight to isoclinal, disharmonic, centimeter-scale folds of the S2 foliation. Foliation strike and lineation trend are parallel to the intrusive contact, suggesting a genetic link between emplacement of the granite and development of D5 structures.

\subsection{D6 deformation}

D6 doming folds the S2 mylonitic foliation, which best defines the dome, and the S3 axial planar surface about a NE-trending fold axis (Figs. 3, 4 and $6 f$ and i). The S2 mylonitic foliation defines a doubly plunging, $\mathrm{N}-\mathrm{S}$ elongate antiformal dome that is larger than the $\sim 28 \mathrm{~km} \times 17 \mathrm{~km}$ area we mapped. The S2 mylonitic foliation dips moderately outward from the center of the dome on the north, west, and south flanks (Figs. 3, 4 and 6f). On the north flank, doming steepened the N-dipping S1 foliation, whereas on the south side, doming rotated the $\mathrm{S} 1$ foliation through horizontal to a moderately southward dip, forming a map-scale, NWtrending D6 synform (Figs. 3, 4 and 6c and q).

\subsection{Brittle structures}

Joints and scarce faults within the dome cut all older penetrative fabrics. Approximately EW-striking, nearvertical joints are developed within the central domain (Fig. 6n). These joints developed orthogonal to Ls2, suggesting a genetic link between the two fabrics. Faults are few, ranging from a small offset (tens of meters), poorly exposed NE-dipping thrust fault at moderate structural levels along the southwest flank of the dome to an approximately $\mathrm{N}$-dipping thrust fault at the northwest end of the map area that places unit Js upon unit Jss; the magnitude of offset is unknown (Figs. 3 and 4). Finally, a steeply SE-dipping fault with down-dip striae cuts unit Ts and the garnet-in isograd (Figs. 3, 4 and 6). Observations including normal-sense drag of units adjacent to the fault, normal-sense shear bands developed within an $\sim 20$-mwide zone of fault gouge and breccia, and normal-sense offset of the garnet-in isograd indicate normal slip across this fault. Because isograds appear to be parallel to lithologic contacts and the S2 foliation, the magnitude of the dip-slip offset of the garnet-in isograd across this fault is $\sim 400-500 \mathrm{~m}$. 


\section{Metamorphic history}

Petrographic examination of thin sections from the pelitic samples reveals a prograde sequence of mineral assemblages that define a series of isograds that increase toward the center of the dome, are roughly concentric to the domal structure defined by the warped stratigraphy, and parallel the lithologic contacts and the S2 foliation (Fig. 6). The lowest grade is distinguished by diagenetic fabrics, scarce detrital muscovite and neocrystallized chlorite. At somewhat deeper structural levels, biotite and prismatic chloritoid join chlorite, defining the chloritoid zone. The breakdown of chloritoid in the presence of biotite yields downsection to garnet + chlorite + biotite. Garnet porphyroblasts are generally sub- to euhedral millimetersize grains. At deeper structural levels, garnet + chlorite assemblages reacted to form staurolite + kyanite + biotite parageneses; kyanite appears before staurolite. Kyanite porphyroblasts typically are blades as large as $5 \mathrm{~mm}$, and staurolites are smaller, anhedral grains; both commonly include garnet. At the deepest structural levels, kyanite and staurolite are joined by fibrous sillimanite, and eventually kyanite disappears.

Microstructures reveal the relative age relations between this first phase of metamorphic porphyroblast growth, which we refer to as M1, and the development of the S2 foliation. (1) Chloritoid porphyroblasts contain inclusion trails defined by fine-grained quartz + white mica + biotite + chlorite that are continuous with the external foliation, S2; the S2 foliation also weakly wraps around the chloritoid porphyroblasts leading to poorly developed strain shadows (Fig. 7a). These microstructural relations show typical synS2 foliation porphyroblast growth. (2) Garnet porphyroblasts exhibit a range of microstructures. Porphyroblasts within the garnet zone contain straight to gently warped inclusion trails defined by quartz, micas, and Fe-oxides that are continuous with the external foliation, S2, and the S2 foliation also weakly wraps around garnet porphyroblasts leading to the development of strain shadows (Fig. 7b). Porphyroblasts within the sillimanite zone lack well-defined inclusion trails but the $\mathrm{S} 2$ foliation wraps around these porphyroblasts, producing strain shadows (Fig. 7c). These textures suggest that garnet growth within the garnet zone was syntectonic with D2 deformation, whereas garnet growth predated D2 deformation in the sillimanite zone. (3) Kyanite porphyroblast textures, ranging from bladed parallel to the $\mathrm{S} 2$ foliation, to bladed with an $\mathrm{Fe}$-oxide inclusion trail that is continuous with the external S2 foliation, to broken and pulled apart within the S2 foliation and bent around garnet porphyroblasts (Fig. 7c), indicate syn-S2 growth. (4) Staurolite porphyroblast habit ranges from small, anhedral grains to large, poikiloblasts. Mediumsized staurolite porphyroblasts locally contain inclusion trails defined by Fe-oxides that are continuous with the external S2 foliation, whereas the S2 foliation moderately wraps around large staurolite porphyroblasts creating strain shadows. These fabrics suggest that staurolite growth occurred syntectonic with D2 deformation. (5) Fibrous sillimanite grows on biotite and kyanite parallel and oblique to the S2 foliation (Fig. 7c), suggesting that this mineral grew late syn- to post-D2 deformation. In summary, these high-grade metamorphic rocks exhibit peak metamorphic conditions, with little or no retrogression, syn- to post-high strain D2 deformation.

The mineral assemblages observed in the Mabja metamorphic zones define a Barrovian metamorphic facies series. At low grade, the stability of chlorite + biotite + chloritoid suggests equilibration conditions of $\sim 475-$ $530{ }^{\circ} \mathrm{C}$ and $\sim 150-450 \mathrm{MPa}$ (Fig. 8) (GIBBS v. 2001; Spear and Menard, 1989), whereas the coexistence of garnet + biotite + chlorite suggests $\sim 575^{\circ} \mathrm{C}$ and $P \geqq 500 \mathrm{MPa}$, the coexistence of kyanite + garnet + staurolite + biotite suggests $\sim 650{ }^{\circ} \mathrm{C}$ and $P \geqq 700 \mathrm{MPa}$, and the nominally invariant AKFM assemblage (kyanite $\rightarrow$ sillimanite $)+$ garnet + staurolite + biotite of the sillimanite zone requires conditions of $\sim 675{ }^{\circ} \mathrm{C}$ and $\sim 750 \mathrm{MPa}$. Thermobarometry was conducted on six pelite samples (Tables 1 and 2); another two chloritoid-zone samples did not yield informatively precise intersections among equilibria. Mineral compositions were measured using a fivespectrometer SX-50 electron probe at UCSB, operated at $15 \mathrm{kV}$ and $15 \mathrm{nA}$. Emphasis was placed on determining the complete compositional zoning/variation of all silicates in different textural settings within each sample. Garnets exhibit a range of zoning characteristics, from garnets with bell-shaped Mn profiles and monotonic increases in $\mathrm{Mg \#}$ characteristic of prograde zoning (samples 29, 49A and 53), to homogeneous garnets with resorbed, Mn-rich rims (samples 42 and 51A); 'intermediate-type' garnets with homogeneous $\mathrm{Mn}$ but zoned $\mathrm{Ca}$ and $\mathrm{Mg}$ indicating partial diffusional homogenization are found in sample 31A. The expected correlation between increasing grade-as indicated by mineral assemblage - and relaxation of garnet zoning or resorbtion is observed in all samples except for 53, which still shows prograde zoning in spite of its high grade, perhaps because it contains the largest $(3 \mathrm{~mm})$ garnets. Biotite and garnet compositions were recalculated to correct for resorbtion, following Kohn and Spear (2000). Individual plagioclase grains and plagioclase textures (comparison among inclusions in garnets, matrix grains, and grains adjacent to garnets) indicate 'core to rim' increases in anorthite content in all samples except 31A. Pressure-temperature conditions (Fig. 8; Table 1) were determined using a combination of GIBBS v. 2001 (Spear and Menard, 1989) and THERMOCALC (Powell and Holland, 1988). Temperatures were calculated using garnet-biotite $\mathrm{Fe}-\mathrm{Mg}$ exchange, and range from $575 \pm 50{ }^{\circ} \mathrm{C}$ in the garnet zone to $705 \pm 65^{\circ} \mathrm{C}$ in the sillimanite zone; these temperatures are compatible with the observed mineral assemblages, although the calculated temperature for sample 53 may be $\sim 50{ }^{\circ} \mathrm{C}$ too high given the preservation of zoning in garnet. Pressures, determined 


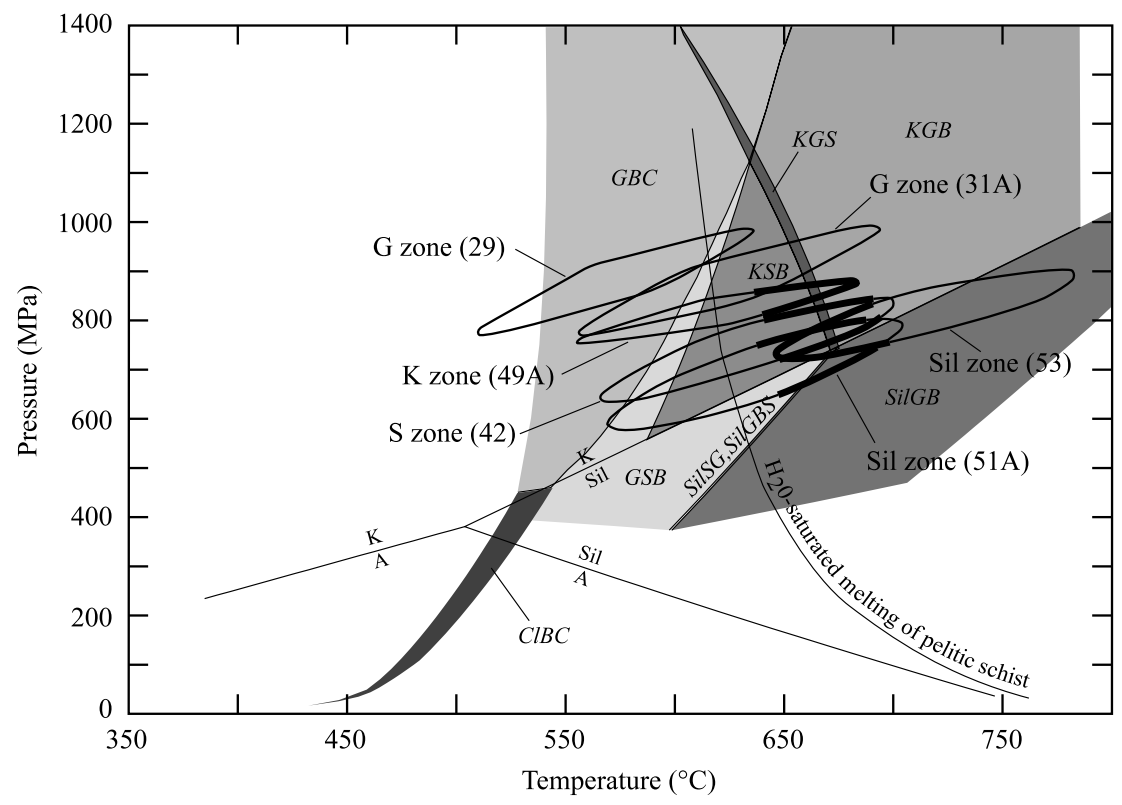

Fig. 8. P/T diagram showing the results of thermobarometry of pelites from the garnet-, staurolite-, and sillimanite zones (see also Table 1), and stability fields for the chloritoid zone. Ellipses represent weighted mean temperatures and pressures for each sample. Heavy lines indicate portion of PT ellipse that falls within the nominal stability field of the minerals in the rock (GIBBS v. 2001; Spear and Menard, 1989). A, andalusite; B, biotite; C, chlorite; Cl, chloritoid; G, garnet; K, kyanite; Sil, sillimanite; S, staurolite. Aluminumsilicate stability fields from Bohlen et al. (1991); other mineral assemblage stability fields, in italics, from Spear and Menard (1989); melting reaction from Thompson and England (1984).

from the anorthite $=$ grossular + kyanite + quartz and garnet + muscovite $=$ anorthite + biotite equilibria, range from $880 \pm 90 \mathrm{MPa}$ in garnet-zone rocks to $820 \pm 100 \mathrm{MPa}$ in sillimanite-zone rocks and are statistically indistinguishable among all the samples. The high pressures calculated in garnet-zone rocks are assumed to be the result of the different activities in the garnet-biotitemuscovite-plagioclase barometer compared with garnetkyanite-quartz-plagioclase barometer. The calculated conditions for sample 51A are perhaps $\sim 100 \mathrm{MPa}$ too high given the presence of the nominally invariant AKFM assemblage kyanite + sillimanite + garnet + staurolite + biotite. Because a minimum of $4-5 \mathrm{~km}$ of structural section overlies the chloritoid-in isograd, we infer pressures of $\sim 150-450 \mathrm{MPa}$ for chloritoid-zone rocks, whereas calculated pressures from garnet-, staurolite-, and sillimanitezone rocks are higher, but constant at $\sim 800 \mathrm{MPa}$, regardless of structural depth (Fig. 8).

A contact metamorphic aureole, defined by andalusite-in, staurolite-in, and sillimanite-in isograds, is well developed

Table 1

Pressures and temperatures

\begin{tabular}{|c|c|c|c|c|c|c|}
\hline Sample & Minerals & $P(\mathrm{MPa})$ & Reaction & $T\left({ }^{\circ} \mathrm{C}\right)$ & Reaction & Correlation \\
\hline 29 & GBMPQ & $880 \pm 90$ & GBMP & $575 \pm 50$ & GARB & 0.92 \\
\hline $31 \mathrm{~A}$ & GBMPQ & $880 \pm 90$ & GBMP & $626 \pm 55$ & GARB & 0.90 \\
\hline \multirow{3}{*}{42} & KGStBMPQ & $720 \pm 160$ & All & $634 \pm 94$ & All & 0.80 \\
\hline & & $730 \pm 90$ & GBMP & $634 \pm 58$ & GARB & 0.83 \\
\hline & & $740 \pm 70$ & GASP & $635 \pm 58$ & GARB & \\
\hline \multirow[t]{2}{*}{$49 \mathrm{~A}$} & KGBMPQ & $820 \pm 50$ & All & $620 \pm 51$ & All & 0.90 \\
\hline & & $820 \pm 90$ & GASP & $620 \pm 51$ & GARB & \\
\hline \multirow[t]{4}{*}{$51 \mathrm{~A}$} & KGStSilBMPQ & $840 \pm 80$ & All & $668 \pm 87$ & All & 0.80 \\
\hline & & $800 \pm 80$ & GBMP & $636 \pm 55$ & GARB & 0.82 \\
\hline & & $780 \pm 100$ & GASP & $635 \pm 55$ & GARB & \\
\hline & & $\sim \mathbf{7 5 0}^{\mathrm{a}}$ & GASP & $\sim 675^{\mathrm{a}}$ & GARB & \\
\hline \multirow[t]{3}{*}{53} & KGStSilBMPQ & $820 \pm 170$ & All & $679 \pm 101$ & All & 0.83 \\
\hline & & $840 \pm 100$ & GBMP & $702 \pm 65$ & GARB & 0.86 \\
\hline & & $820 \pm 100$ & GASP & $705 \pm 65$ & GARB & \\
\hline
\end{tabular}

Preferred values in bold. GARB $=$ garnet-biotite thermometer. GASP $=$ garnet-kyanite-quartz-plagioclase barometer. GBMP $=$ garnet-biotitemuscovite-plagioclase barometer. All = all equilibria among garnet, biotite, muscovite, plagioclase, kyanite, and quartz, excluding celadonite and eastonite activities. Temperature uncertainty of GARB-GASP intersection is assumed to be $50{ }^{\circ} \mathrm{C}$ or that of the GARB-GBMP intersection, whichever is larger. B, biotite; G, garnet; K, kyanite; M, muscovite; P, plagioclase; Q, quartz; St, staurolite; Sil, sillimanite.

a Inferred on the basis of the mineral assemblage (kyanite $\rightarrow$ sillimanite $)+$ garnet + staurolite + biotite. 
Table 2

Mineral analyses

\begin{tabular}{|c|c|c|c|c|c|c|c|c|c|c|c|c|c|c|c|c|c|c|c|c|c|c|c|}
\hline Sample mineral & $\begin{array}{l}29 \\
\text { fsp \#326 }\end{array}$ & $\begin{array}{l}29 \\
\text { bi \#239 }\end{array}$ & $\begin{array}{l}29 \\
\mathrm{mu} \# 291\end{array}$ & $\begin{array}{l}29 \\
\mathrm{~g} \# 261\end{array}$ & $\begin{array}{l}31 \mathrm{~A} \\
\text { fsp \#26 }\end{array}$ & $\begin{array}{l}31 \mathrm{~A} \\
\mathrm{~g} \# 129\end{array}$ & $\begin{array}{l}31 \mathrm{~A} \\
\mathrm{bi} \# 11\end{array}$ & $\begin{array}{l}31 \mathrm{~A} \\
\mathrm{mu} \# 4\end{array}$ & $\begin{array}{l}42 \\
\text { fsp \#5 }\end{array}$ & $\begin{array}{l}42 \\
\mathrm{~g} \# 100\end{array}$ & $\begin{array}{l}42 \\
\text { bi \#166 }\end{array}$ & $\begin{array}{l}42 \\
\mathrm{mu} \# 112\end{array}$ & $\begin{array}{l}49 \mathrm{~A} \\
\mathrm{~g} \# 49\end{array}$ & $\begin{array}{l}49 \mathrm{~A} \\
\text { fsp \#11 }\end{array}$ & $\begin{array}{l}49 \mathrm{~A} \\
\text { bi \#98 }\end{array}$ & $\begin{array}{l}51 \mathrm{~A} \\
\text { fsp \#276 }\end{array}$ & $\begin{array}{l}51 \mathrm{~A} \\
\text { bi } \# 210\end{array}$ & $\begin{array}{l}51 \mathrm{~A} \\
\text { bi } \# 49\end{array}$ & $\begin{array}{l}51 \mathrm{~A} \\
\mathrm{mu} \# 65\end{array}$ & $\begin{array}{l}53 \\
\mathrm{~g} \# 352\end{array}$ & $\begin{array}{l}53 \\
\text { fsp \#451 }\end{array}$ & $\begin{array}{l}53 \\
\text { bi \#493 }\end{array}$ & $\begin{array}{l}53 \\
\mathrm{mu} \# 421\end{array}$ \\
\hline $\mathrm{SiO}_{2}$ & 59.94 & 35.79 & 46.09 & 37.64 & 57 & 37.64 & 36.14 & 46.12 & 61.99 & 37.2 & 36.23 & 45.55 & 36.93 & 61.03 & 37.01 & 61.74 & 34.46 & 36.48 & 45.46 & 37.11 & 60.88 & 34.92 & 45.55 \\
\hline $\mathrm{TiO}_{2}$ & 0 & 1.88 & 0.42 & 0.06 & 0.02 & 0.06 & 2.09 & 0.4 & 0 & 0 & 2.15 & 0.53 & 0.02 & 0 & 1.53 & 0.01 & 1.86 & 2.01 & 0.74 & 0 & 0.01 & 1.81 & 0.21 \\
\hline $\mathrm{Al}_{2} \mathrm{O}_{3}$ & 25.61 & 18.96 & 35.35 & 21.43 & 25.9 & 21.65 & 18.72 & 33.61 & 23.77 & 21.5 & 19.53 & 36.14 & 21.72 & 25.12 & 19.57 & 23.59 & 18.34 & 19.38 & 34.66 & 21.19 & 24.88 & 19.91 & 37.02 \\
\hline $\mathrm{Cr}_{2} \mathrm{O}_{3}$ & 0.03 & 0.04 & 0.02 & 0.01 & 0.06 & 0 & 0.02 & 0.03 & 0 & 0.03 & 0 & 0 & 0.04 & 0 & 0 & 0 & 0 & 0.05 & 0 & 0.03 & 0.03 & 0.06 & 0.03 \\
\hline $\mathrm{Fe}_{2} \mathrm{O}_{3}$ & 0 & 0 & 0 & 1.54 & 0.07 & 1.53 & 0 & 0 & 0 & 1.47 & 0 & 0 & 1.51 & 0 & 0 & 0 & 0 & 0 & 0 & 1.86 & 0.04 & 0 & 0 \\
\hline $\mathrm{FeO}$ & 0 & 18.96 & 1.77 & 29.65 & 0 & 30.83 & 16.68 & 1.4 & 0 & 32.68 & 18.87 & 1.28 & 29.47 & 0 & 16.05 & 0 & 19.59 & 15.62 & 1.82 & 33.72 & 0 & 19.48 & 1.15 \\
\hline $\mathrm{MnO}$ & 0 & 0.05 & 0 & 0.76 & 0 & 0.39 & 0.04 & 0.02 & 0 & 3.06 & 0.1 & 0 & 3.47 & 0 & 0.14 & 0.02 & 0.13 & 0.07 & 0 & 0.92 & 0 & 0.07 & 0.01 \\
\hline $\mathrm{MgO}$ & 0 & 10.38 & 0.83 & 2.01 & 0 & 3.12 & 11.4 & 1.07 & 0.01 & 3.3 & 9.7 & 0.66 & 3.84 & 0 & 11.96 & 0.01 & 9.8 & 11.38 & 0.64 & 3.58 & 0.01 & 8.81 & 0.53 \\
\hline $\mathrm{CaO}$ & 7.17 & 0.02 & 0.01 & 8.61 & 8.54 & 6.41 & 0.02 & 0 & 5.2 & 2.2 & 0.05 & 0 & 3.39 & 6.2 & 0.01 & 5.44 & 0 & 0 & 0.01 & 2.61 & 6 & 0 & 0 \\
\hline $\mathrm{Na}_{2} \mathrm{O}$ & 7.64 & 0.18 & 0.88 & 0 & 6.95 & 0 & 0.14 & 0.55 & 8.57 & 0 & 0.25 & 1.21 & 0 & 7.96 & 0.29 & 8.4 & 0.28 & 0.38 & 1.07 & 0 & 8.12 & 0.2 & 1.08 \\
\hline $\mathrm{K}_{2} \mathrm{O}$ & 0.07 & 8.93 & 10.1 & 0.01 & 0.09 & 0.02 & 9.33 & 10.64 & 0.18 & 0 & 8.67 & 9.57 & 0 & 0.08 & 8.79 & 0.17 & 9.64 & 9.48 & 9.98 & 0 & 0.17 & 8.97 & 9.65 \\
\hline Totals & 100.46 & 95.2 & 95.48 & 101.71 & 98.63 & 101.65 & 94.59 & 93.85 & 99.72 & 101.44 & 95.56 & 94.95 & 100.39 & 100.39 & 95.36 & 99.38 & 94.11 & 94.86 & 94.39 & 101.02 & 100.14 & 94.24 & 95.24 \\
\hline Oxygens & 8 & 11 & 11 & 12 & 8 & 12 & 11 & 11 & 8 & 12 & 11 & 11 & 12 & 8 & 11 & 8 & 11 & 11 & 11 & 12 & 8 & 11 & 11 \\
\hline $\mathrm{Si}$ & 2.659 & 2.71 & 3.066 & 2.958 & 2.592 & 2.952 & 2.73 & 3.123 & 2.755 & 2.95 & 2.722 & 3.034 & 2.935 & 2.699 & 2.747 & 2.754 & 2.676 & 2.733 & 3.064 & 2.95 & 2.702 & 2.682 & 3.02 \\
\hline $\mathrm{Ti}$ & 0 & 0.107 & 0.021 & 0.004 & 0.001 & 0.004 & 0.119 & 0.02 & 0 & 0 & 0.122 & 0.027 & 0.001 & 0 & 0.085 & 0 & 0.109 & 0.113 & 0.038 & 0 & 0 & 0.105 & 0.01 \\
\hline $\mathrm{Al}$ & 1.339 & 1.693 & 2.772 & 1.986 & 1.389 & 2.001 & 1.667 & 2.684 & 1.245 & 2.01 & 1.73 & 2.838 & 2.035 & 1.31 & 1.712 & 1.241 & 1.679 & 1.712 & 2.754 & 1.986 & 1.302 & 1.802 & 2.894 \\
\hline $\mathrm{Cr}$ & 0.001 & 0.002 & 0.001 & 0.001 & 0.002 & 0 & 0.001 & 0.002 & 0 & 0.002 & 0 & 0 & 0.003 & 0 & 0 & 0 & 0 & 0.003 & 0 & 0.002 & 0.001 & 0.004 & 0.002 \\
\hline $\mathrm{Fe}_{3}$ & 0 & 0 & 0 & 0.091 & 0.002 & 0.09 & 0 & 0 & 0 & 0.087 & 0 & 0 & 0.09 & 0 & 0 & 0 & 0 & 0 & 0 & 0.111 & 0.001 & 0 & 0 \\
\hline $\mathrm{Fe}_{2}$ & 0 & 1.201 & 0.098 & 1.949 & 0 & 2.022 & 1.054 & 0.079 & 0 & 2.168 & 1.186 & 0.071 & 1.959 & 0 & 0.996 & 0 & 1.272 & 0.979 & 0.103 & 2.242 & 0 & 1.251 & 0.064 \\
\hline $\mathrm{Mn}$ & 0 & 0.003 & 0 & 0.051 & 0 & 0.026 & 0.003 & 0.001 & 0 & 0.206 & 0.006 & 0 & 0.234 & 0 & 0.009 & 0.001 & 0.009 & 0.004 & 0 & 0.062 & 0 & 0.005 & 0.001 \\
\hline $\mathrm{Mg}$ & 0 & 1.172 & 0.082 & 0.235 & 0 & 0.365 & 1.283 & 0.108 & 0.001 & 0.39 & 1.086 & 0.066 & 0.455 & 0 & 1.323 & 0.001 & 1.134 & 1.271 & 0.064 & 0.424 & 0.001 & 1.008 & 0.052 \\
\hline $\mathrm{Ca}$ & 0.3 & 0.002 & 0.001 & 0.725 & 0.416 & 0.539 & 0.002 & 0 & 0.248 & 0.187 & 0.004 & 0 & 0.289 & 0.294 & 0.001 & 0.26 & 0 & 0 & 0.001 & 0.223 & 0.285 & 0 & 0 \\
\hline $\mathrm{Na}$ & 0.657 & 0.026 & 0.113 & 0 & 0.613 & 0 & 0.021 & 0.072 & 0.738 & 0 & 0.036 & 0.156 & 0 & 0.683 & 0.042 & 0.727 & 0.042 & 0.055 & 0.14 & 0 & 0.699 & 0.03 & 0.139 \\
\hline K & 0.004 & 0.864 & 0.858 & 0.001 & 0.005 & 0.002 & 0.9 & 0.92 & 0.01 & 0 & 0.832 & 0.814 & 0 & 0.005 & 0.833 & 0.01 & 0.956 & 0.907 & 0.859 & 0 & 0.01 & 0.88 & 0.817 \\
\hline Sum & 5.001 & 7.780 & 7.013 & 8.000 & 5.020 & 8.000 & 7.778 & 7.010 & 4.997 & 8.000 & 7.725 & 7.006 & 8.000 & 4.990 & 7.749 & 4.993 & 7.875 & 7.777 & 7.021 & 8.000 & 5.000 & 7.766 & 6.999 \\
\hline
\end{tabular}


around the Kouwu granite (Fig. 6). This second metamorphic event, M2, is superimposed upon the older M1 isograds. Textures show that andalusite overgrew older (M1) garnet porphyroblasts and the S2 foliation (Fig. 7d), was associated with the growth of new biotite and chlorite porphyroblasts, and grew at the same time as the S5 foliation developed. These relations indicate that andalusite grew after D2 deformation and during D5 deformation and emplacement of the Kouwu granite. This conclusion is consistent with our mesoscopic observation that andalusite grains are randomly oriented on the S2 foliation surface. Porphyroblasts of staurolite also overgrew the S2 foliation and thin wisps of sillimanite locally replace the rims of biotite and andalusite.

Four salient observations fall from the M1 metamorphic petrology. (1) The presence of pressures as high as $800 \mathrm{MPa}$ suggests that these rocks were thickened or buried. This inference is consistent with microtextural relations that show growth of peak index minerals after D1 folding and during to after D2 deformation. (2) Based on PT determinations outlined above, apparent isotherms can be drawn that increase with structural depth, yielding a metamorphic field gradient of $10-60{ }^{\circ} \mathrm{C} / \mathrm{km}$. (3) The apparent gradient in pressure between the chloritoid-in isograd and garnet-zone rocks is $\sim 50-270 \mathrm{MPa} / \mathrm{km}$, well in excess of the expected gradient of $27 \mathrm{MPa} / \mathrm{km}$ for supracrustal rocks with a density of $2700 \mathrm{~kg} / \mathrm{m}^{3}$. The development of such a subvertically foreshortened pressure gradient requires a factor of $\sim 2-10$ subhorizontal stretching ( 50-10\% vertical thinning) after the pressure gradient was frozen in. Given the well-developed mylonitic S2 foliations, NS-trending Ls2 stretching lineations, ribbon quartz grains, and degree of boudinage, a factor of $\sim 4-10$ horizontal stretching ( $\sim 25-10 \%$ vertical thinning) is more likely. (4) Sillimanite-zone rocks exposed at the deepest structural levels yield calculated metamorphic pressures that are the same as, but temperatures that are higher than, garnet- and kyanite-zone rocks at shallower structural levels. Two possible interpretations can explain this relation. First, the peak pressures and temperatures recorded in garnet- to sillimanite-zone rocks may have occurred at the same time in a single structural horizon at $\sim 30 \mathrm{~km}$ depth. This geometry defines a horizontal temperature difference of $\sim 15-245^{\circ} \mathrm{C}$ from garnet- to sillimanite-zone rocks and yields a horizontal field gradient of $\sim 1-20^{\circ} \mathrm{C} / \mathrm{km}$. A consequence of this interpretation is that the structural geometry has not changed since peak metamorphism was recorded in the rocks at $\sim 30 \mathrm{~km}$ depth. This interpretation seems unlikely because doming, in part, occurred after formation of the S2 foliation and M1 metamorphic isograds. The second interpretation is that peak pressures and temperatures occurred at different times, such that garnetzone rocks reached peak metamorphic conditions at $\sim 30 \mathrm{~km}$ depth before kyanite-zone rocks reached peak conditions at the same depth, which in turn reached peak conditions before sillimanite-zone rocks, again at the same depth. This interpretation is more consistent with field and microstructural relations, and indicates heating during exhumation.

\section{Discussion}

\subsection{Formation of the Mabja Gneiss Dome}

A number of observations from Mabja Dome indicate that rocks at deep structural levels were exhumed, at least in part, during M1 metamorphism, D2 extensional deformation, partial melting, and emplacement of the leucocratic dike swarm. Microtextural relations indicate that garnet, kyanite, staurolite, and sillimanite grew syn- to post-D2 extensional deformation. The subvertically foreshortened pressure gradient at intermediate structural depths, from the chloritoid-in isograd to garnet-zone rocks, of $\sim 120$ $270 \mathrm{MPa} / \mathrm{km}$, requires that these rocks were vertically thinned to $\sim 25-10 \%$ of their original thickness (horizontally stretched by a factor of 4-10) after the pressure gradient was recorded in the rocks. Quantitative metamorphic petrology also indicates that garnet-, kyanite-, staurolite-, and sillimanite-zone rocks record increasing temperatures with increasing structural depths, but the same pressure, implying heating during exhumation. At the deepest structural levels, leucosomes and melanosomes were deformed during D2 deformation, indicating partial melting syntectonic with D2. Finally, pegmatites exhibit local segregation bands of quartz and feldspar and nearly $100 \%$ biotite and a range of structures indicating emplacement and partial melting during late D2 deformation.

These data suggest a structural and metamorphic history characterized by three principal steps (Fig. 9). The rocks exposed within Mabja were thickened and buried by distributed folding during D1 deformation, such that chloritoid-zone rocks were buried to $\geqq 5.5 \mathrm{~km}$ depth, garnet-zone rocks were buried to $\sim 30 \mathrm{~km}$ depth, and kyanite- to sillimanite-zone rocks were buried to even greater pressures not recorded in the rocks (Fig. 9a). Thermal relaxation following D1 thickening led to M1 metamorphism and generation of migmatites at deep structural levels. During M1 metamorphism, Mabja rocks were subhorizontally stretched by a factor of $\sim 4-10$, collapsing the chloritoid and garnet isobars to $\sim 25-10 \%$ of their original thickness (Fig. 9b and c). The resultant finite strain of $\geqq 16: 1(X: Z)$ is consistent with observed welldeveloped mylonitic S2 foliations, NS-trending Ls2 stretching lineations, ribbon quartz grains, and degree of boudinage. High temperature kinematic indicators associated with the development of the S2 foliation are dominantly symmetric, indicating that deformation was largely coaxial. Conductive relaxation of isotherms following D1 thickening is a reasonable explanation for peak metamorphism, but it does not explain the input of heat required by the observed increase in temperatures for 


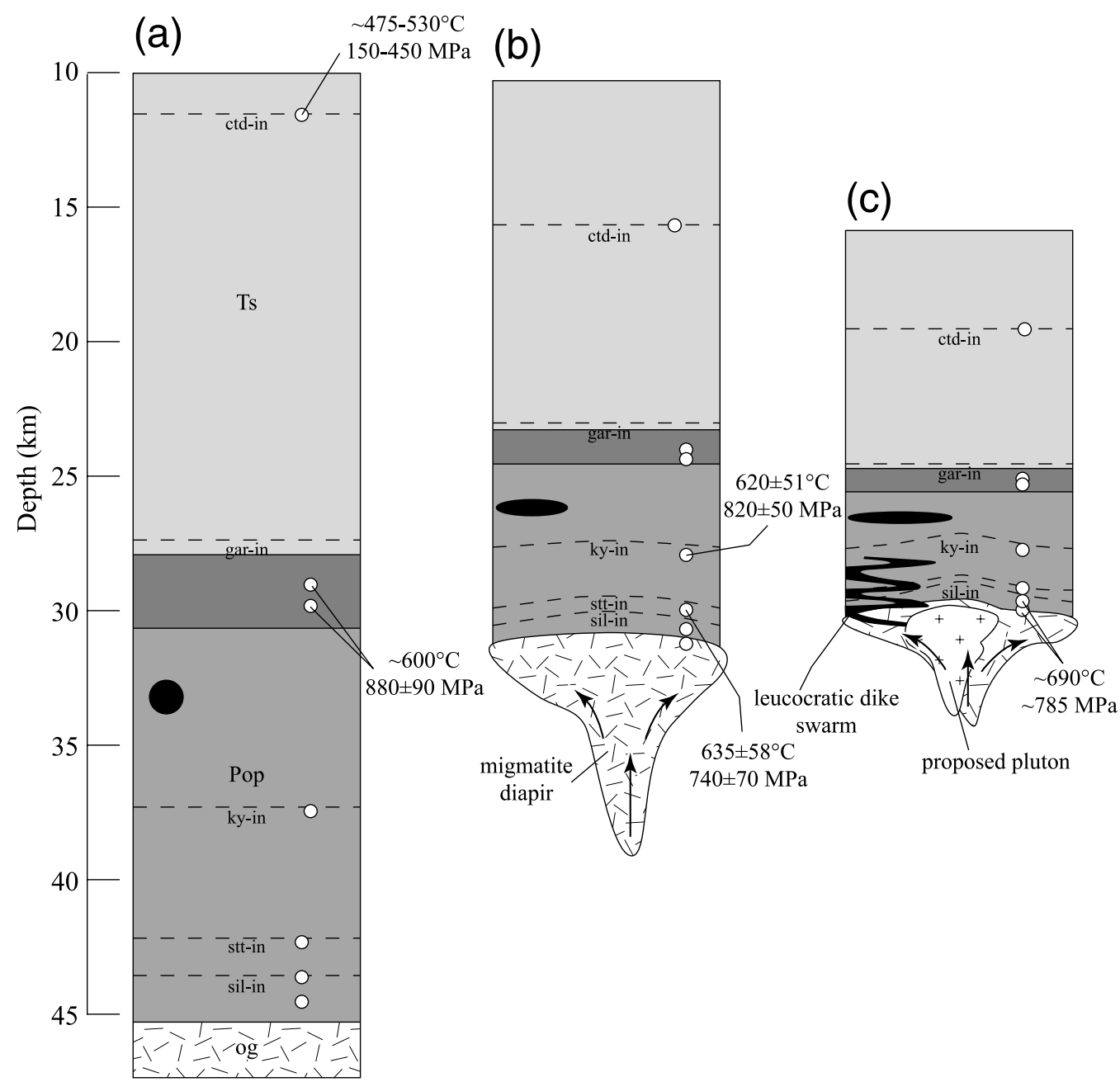

Fig. 9. Proposed structural evolution for Mabja Dome. (a) D1 folding and thickening leads to recorded peak pressures of $\sim 150-450$ and $\sim 880 \mathrm{MPa}$ in chloritoid- and garnet-zone rocks, respectively. (b) Early stages of D2 vertical thinning, horizontal stretching, and exhumation of previously thickened rocks. Adiabatic decompression during extensional collapse generates buoyant migmatite diapirs. Pressures of $\sim 800 \mathrm{MPa}$ and temperatures of $\sim 630{ }^{\circ} \mathrm{C}$ recorded in kyanite- and staurolite-zone rocks. (c) Final stages of D2 vertical thinning and horizontal stretching. Late D2 emplacement of leucocratic dike swarm. Pressures of $\sim 785 \mathrm{MPa}$ and temperatures of $\sim 690^{\circ} \mathrm{C}$ recorded in sillimanite-zone rocks. ctd-in, chloritoid-in isograd; gar-in, garnet-in isograd; ky-in, kyanite-in isograd; stt-in, staurolite-in isograd; sil-in, sillimanite-in isograd; open circles are samples analyzed for quantitative thermobarometry; solid ellipses are schematic strain markers.

sillimanite-zone rocks that record the same metamorphic pressure as the structurally shallower garnet-zone rocks. We propose that a large plutonic body, below the level of exposures that we mapped, was the source of that additional heat; the leucocratic dike swarm may be the field evidence for this deeper seated pluton (Fig. 9c). If true, this implies two metamorphic events closely linked in space and time and suggests that input of heat contributed to the development of migmatites. Finally, the proposed pluton may be an earlier episode of the same magmatic event that generated the two-mica granites, although the latter were emplaced at somewhat shallower crustal levels after the D2 deformation.

The above discussion is predicated on some important assumptions. Given that D2 structures are characterized by well-developed LS tectonites, we have assumed plane strain deformation. We also assumed that the peak pressures of the chloritoid- and garnet-zone rocks reflect an original structural separation, but it is possible that garnet growth was separated from chloritoid growth by some component of D2 extensional collapse. In contrast, we assumed that PT estimates from deep structural levels were locked in at different times, implying that temperatures were increasing while the rocks moved through the $\sim 800 \mathrm{MPa}$ depth on their way to shallower levels. Note that because metamorphic field gradients are defined by the spatial distribution of peak temperatures that occurred at different times, the apparent thermal gradient defined by Mabja Dome samples $\left(\sim 5-10^{\circ} \mathrm{C} / \mathrm{km}\right)$ (Fig. 9a) has no simple relationship to thermal gradients that actually existed during the tectonic history.

At least three possible processes may explain the simultaneous heating, exhumation, partial melting, and emplacement of the leucocratic dike swarm at deep structural levels that we have documented within Mabja 
Dome. Le Fort and co-workers (Le Fort, 1986; Le Fort et al., 1987) suggested that thrusting along the Main Central Thrust of hot portions of the Tibetan Slab over weakly metamorphosed sediments resulted in large-scale release of fluids that rose above the Main Central Thrust and induced anatexis. Numerical simulations by Harrison et al. (1997) suggest that anatexis, caused by heat generated due to shear stress along the Himalayan décollement, resulted in the emplacement of leucogranites exposed within the North Himalayan gneiss domes. In contrast to these contractionrelated processes, ductile thinning of the lower part of overthickened crust results in collapse and decompression (Rey, 1993), and, if the decompression is rapid enough to overcome conductive cooling, partial melting (Teyssier and Whitney, 2002). An outcome of partial melting is a hot and weak lower crust, which promotes crustal thinning and collapse, which in turn causes decompression, resulting in positive feedback (Teyssier and Whitney, 2002). A consequence of each scenario is that low-density, lowviscosity molten to partially molten crust may rise diapirically into the middle crust, producing the domal form characteristic of gneiss domes.

Because of the close spatial and temporal relations among metamorphism, partial melting, emplacement of the dike swarm, and D2 extensional deformation in Mabja, we favor a doming mechanism driven, at least in part, by buoyant migmatite diapirs generated during adiabatic decompression and possibly enhanced by a buoyant granitic body at depth (Fig. 9b and c). We suggest that shear heat along the Himalayan décollement (Harrison et al., 1997) generated the proposed granitic pluton. The absence of radial and tangential lineation patterns, of a dome-up sense of shear centered on the dome apex, and of strain that increases toward the core-cover contact-geometries expected in a dome that formed solely by diapirism (e.g. Schwerdtner et al., 1978; Bateman, 1984; Jelsma et al., 1993) — combined with the observation that the $S 2$ foliation and M1 metamorphic isograds are domed, are consistent with the emplacement of a diapir into Mabja Dome during regional mid-crustal extensional deformation and metamorphism. We cannot, however, determine the relative contributions of thermal relaxation following crustal thickening, horizontal extensional deformation, adiabatic decompression, and emplacement of a granitic pluton beneath the core of the dome to metamorphism, development of migmatites, and regional mid-crustal extension.

Alternative end-member mechanisms for doming, extension and contraction are not viable because we did not observe key features such as a fault or shear zone contact between the core and cover, a unidirectional sense of shear, and faults or folds at high structural levels that accommodated the associated deeper structural level penetrative strain. Nevertheless, based on the field, structural, and metamorphic data presented here, we cannot exclude the possibility that regional extension and/or contraction contributed to the development of the domal form (cf. Lee et al., 2000). Thermochronologic data from the Kangmar Dome were the key dataset that resulted in Lee et al.'s (2000) conclusion that the domal geometry was the result of mid-crustal rocks thrust up and over a ramp. Similar data from Mabja Dome may also resolve the issue of whether regional extension and/or contraction contributed to the domal geometry.

\subsection{Tectonic implications}

The structural and metamorphic events preserved in Mabja and Kangmar (Lee et al., 2000) domes are similar and consist of four primary events: (1) D1 deformation characterized by NS-contraction leading to folding and thickening, (2) thermal re-equilibration of middle crustal rocks resulting in peak metamorphism, (3) high-strain D2 vertical thinning and horizontal extension during to after peak metamorphism, and (4) development of a domal geometry defined by lithologic contacts at deeper structural levels, the S2 mylonitic foliation, and metamorphic isograds. Furthermore, thermochronologic studies yield middle Miocene cooling ages in Mabja Dome (Lee et al., 2002), the same as in Kangmar Dome (Lee et al., 2000), and both domes lie in the hanging wall of the GyirongKangmar thrust fault system (Fig. 1). The remarkable similarities between the two domes suggest that the physical processes that produced both domes may have been responsible for the other North Himalayan gneiss domes. On the other hand, the migmatites, the late leucocratic dike swarm, and the post-tectonic two-mica granites of Mabja Dome were not found in Kangmar Dome (Lee et al., 2000)_perhaps because Mabja exposes deeper structural levels than Kangmar. In addition, domed mica ${ }^{40} \mathrm{Ar} /{ }^{39} \mathrm{Ar}$ chrontours that increase in age with depth in Kangmar led Lee et al. (2000) to conclude that dome formation resulted from development of an antiform above a north-dipping ramp along the Gyirong-Kangmar thrust fault system and occurred after mid-crustal extension. Because Mabja Dome also lies in the hanging wall of the Gyirong-Kangmar thrust fault system, it seems reasonable to suggest that dome formation continued after diapirism and mid-crustal extension by the same relatively low temperature $\left(\leq 400{ }^{\circ} \mathrm{C}\right)$ contractional mechanism. However, on the basis of our field, structural, and metamorphic data, and in the absence of mica ${ }^{40} \mathrm{Ar} /{ }^{39} \mathrm{Ar}$ data, we cannot prove this conjecture.

As in studies in Kangmar Dome (Burg et al., 1984; Chen et al., 1990; Lee et al., 2000), this investigation does not constrain the timing of D1 NS-contractional structures. Studies in the Annupurna (Hodges et al., 1996; Vannay and Hodges, 1996; Godin et al., 1999) and Ladakh-Zanskar regions (Searle et al., 1988) led to the inference of an early to middle Eocene age for this contractional event. Because we did not observe normal faults that could have accommodated the syn-metamorphic penetrative D2 extensional deformation, we follow Lee et al.'s (2000) interpretation that to maintain strain compatibility, middle crustal 
collapse (thinning) was accommodated at shallow crustal levels by normal slip along the Southern Tibetan detachment system. In this interpretation, shallow, brittle slip along the Southern Tibetan detachment system terminated at middle crustal depths into a root zone of bulk coaxial to noncoaxial D2 strain presently exposed in Mabja and Kangmar (Chen et al., 1990; Lee et al., 2000) domes. The driving force for normal slip along the Southern Tibetan detachment system, and thereby the development of middle crustal extensional fabrics in Mabja and Kangmar domes, has been ascribed to gravitational collapse of overthickened crust or a reduction in the coefficient of friction along the Main Himalayan Thrust (e.g. Burchfiel and Royden, 1985; Royden and Burchfiel, 1987).

A number of geophysical observations, including shortwavelength gravity anomalies (Jin et al., 1994), and the coincidence of high electrical conductivity, middle crustal low velocities, and reflection bright spots (Chen et al., 1996; Makovsky et al., 1996; Nelson et al., 1996), have been interpreted to indicate that the middle crust beneath southern Tibet is hot, partially molten, and weak. We suggest that migmatites and partial melts in Mabja Dome and the high temperature metamorphic rocks in Kangmar Dome are exposures of this once hot and weak middle crust of the Miocene. Finally, we propose that the emplacement of the post-D2 two-mica granites documented in Mabja Dome indicates either a time lag between the onset of collapse-driven adiabatic decompression, melting, and subsequent diapiric rise, or a change to contractiondominated deformation resulting in increased shear stress along the Main Himalayan Thrust, anatexis, and the generation of two-mica granites (e.g. Harrison et al., 1997).

\section{Conclusions}

Structural and metamorphic petrology investigations in Mabja Dome reveal three major phases of deformation. The first phase of deformation, NS contraction that resulted in thickening in the Mabja region, was followed by thermal reequilibration and Barrovian metamorphism during a second phase of deformation characterized by horizontal extension and vertical thinning. At the deepest structural levels, extension continued simultaneously with emplacement of a pegmatite and aplite dike swarm, development of migmatites, and initiation of doming. We attribute doming, at least in part, to diapiric rise of migmatites produced by thermal re-equilibration and adiabatic decompression during regional extensional collapse, possibly enhanced by an unexposed granitic pluton beneath the core of the dome. The structural and metamorphic histories of Mabja Dome are similar to those of Kangmar Dome, suggesting that these events were of regional extent during the Miocene. However, the mechanism of dome formation-diapirism during extension in Mabja, and development of an antiform above a thrust ramp in Kangmar Dome-are different.
Based on the data presented in this paper, a contractional mechanism contributing to the domal geometry cannot be ruled out for Mabja Dome. Detailed thermochronologic data are needed to address this issue. The migmatites exposed in Mabja likely represent the Miocene equivalent to the partially molten crust interpreted to reside at middle crustal depths beneath southern Tibet today. As was proposed for Kangmar Dome, we suggest that middle crustal extension deformation in Mabja Dome occurred within a zone of coaxial to noncoaxial strain in the root zone of the Southern Tibetan detachment system.

\section{Acknowledgements}

Funding for this project was provided by National Science Foundation grants EAR-9526861 and EAR0003568, and National Science Foundation Grant of China 49473171. We thank P. Gans and L. Qi for assistance in the field and R. Allmendinger for use of his stereonet software. Comments by $\mathrm{S}$. Wallis on an earlier version of this manuscript and reviews by R. Brown, J. Platt, and JSG editor D.A. Ferrill improved the clarity of our presentation.

\section{References}

Armijo, R., Tapponnier, P., Mercier, J., Han, T., 1986. Quaternary extension in southern Tibet: field observations and tectonic implications. Journal of Geophysical Research 91, 13803-13872.

Bateman, R., 1984. On the role of diapirism in the segregation, ascent, and final emplacement of granitoid magmas. Tectonophysics 110, $211-231$

Bohlen, S.R., Montana, A., Kerrick, D.M., 1991. Precise determinations of the equilibria kyanite $=$ sillimanite and kyanite $=$ andalusite and a revised triple point for $\mathrm{Al}_{2} \mathrm{SiO}_{5}$ polymorphs. American Mineralogist 76, $677-680$.

Brown, M., 1994. The generation, segregation, ascent and emplacement of granite magma: the migmatite-to-crustally-derived granite connection in thickened orogens. Earth-Science Reviews 36, 83-130.

Brown, M., Johnson, T., Marchildon, N., Solar, G., 2002. Controls on gneiss dome formation; chickens, eggs and red herrings. Geological Society America Abstracts 36, 107.

Brun, J.-P., 1983. L'origine des domes gneissiques: modeles et tests. Bulletin de la Societe Geologique de France 25, 219-228.

Brun, J.-P., Pons, J., 1981. Strain patterns of pluton emplacement in a crust undergoing non-coaxial deformation, Sierra Morena, southern Spain. Journal of Structural Geology 3, 219-230.

Brun, J.P., Van Den Driessche, J., 1994. Extensional gneiss domes and detachment faults-structure and kinematics. Bulletin de la Societe Geologique de France 165, 519-530.

Burchfiel, B.C., Royden, L.H., 1985. North-south extension within the convergent Himalayan region. Geology 13, 679-682.

Burchfiel, B.C., Zhiliang, C., Hodges, K.V., Yuping, L., Royden, L.H., Changrong, D., Jiene, X., 1992. The south Tibetan detachment system, Himalayan orogen: extension contemporaneous with and parallel to shortening in a collisional mountain belt. Geological Society America Special Paper 269, 41pp.

Burg, J.P., Chen, J.M., 1984. Tectonics and structural zonation of southern Tibet, China. Nature 311, 219-223.

Burg, J.P., Guiraud, M., Chen, G.M., Li, G.C., 1984. Himalayan 
metamorphism and deformations in the north Himalayan Belt (southern Tibet, China). Earth and Planetary Science Letters 69, 391-400.

Calvert, A.T., Gans, P.B., Amato, J.M., 1999. Diapiric ascent and cooling of a sillimanite gneiss dome revealed by ${ }^{40} \mathrm{Ar} /{ }^{39} \mathrm{Ar}$ thermochronology: the Kigluaik Mountains, Seward Peninsula, Alaska. In: Ring, U., Brandon, M.T., Lister, G.S., Willett, S.D., (Eds.), Exhumation Processes: Normal Faulting, Ductile Flow, and Erosion, Geological Society Special Publication, 154., pp. 205-232.

Chen, L., Booker, J.R., Jones, A.G., Nong, W., Unsworth, M.J., Wenbo, W., Handong, T., 1996. Electrically conductive crust in southern Tibet from INDEPTH magnetotelluric surveying. Science 274, 1694-1696.

Chen, Z., Liu, Y., Hodges, K.V., Burchfiel, B.C., Royden, L.H., Deng, C., 1990. The Kangmar Dome: a metamorphic core complex in southern Xizang (Tibet). Science 250, 1552-1556.

Coward, M.P., 1981. Diapirism and gravity tectonics. Report of a Tectonic Studies Group conference held at Leeds University, 25-26 March 1980. Journal of Structural Geology 3, 89-95

Crittenden, M.D.J., Coney, P.J., Davis, G.H., 1980. Cordilleran Metamorphic Core Complexes. Geological Society America Memoir 153, Boulder, CO.

Dahlen, F.A., 1990. Critical taper model of fold-and-thrust belts and accretionary wedges. Annual Reviews in Earth and Planetary Sciences 18, 55-99.

Davis, G.A., Lister, G.S., Reynolds, S.J., 1986. Structural evolution of the Whipple and South Mountains shear zones, southwestern United States. Geology 14, 7-10.

Dixon, J.M., Summers, J.M., 1983. Patterns for total and incremental strain in subsiding troughs: experimental centrifuged models of inter-diapir synclines. Canadian Journal of Earth Sciences 20, 1843-1861.

Escuder Viruete, J., Arenas, R., Martinez Catalan, J.R., 1994. Tectonothermal evolution associated with Variscan crustal extension in the Tormes Gneissic Dome (NW Salamanca, Iberian Massif, Spain). Tectonophysics 238, 117-138.

Eskola, P.E., 1949. The problem of mantled gneiss domes. Quarterly Journal of the Geological Society of London 104, 461-476.

Gansser, A., 1964. Geology of the Himalayas, Wiley-Interscience, London.

Godin, L., Brown, R.L., Hanmer, S., Parrish, R., 1999. Back folds in the core of the Himalayan orogen: an alternative interpretation. Geology $27,151-154$.

Harrison, T.M., Lovera, O.M., Grove, M., 1997. New insights into the origin of two contrasting Himalayan granite belts. Geology 25, 899-902.

Hodges, K.V., Parrish, R.R., Searle, M.P., 1996. Tectonic evolution of the central Annapurna range, Nepalese Himalayas. Tectonics 15, $1264-1291$

Holm, D.K., Lux, D.R., 1996. Core complex model proposed for gneiss dome development during collapse of the Paleoproterozoic Penokean Orogen, Minnesota. Geology 24, 343-346.

Hurlow, H.A., Snoke, A.W., Hodges, K.V., 1991. Temperature and pressure of mylonitization in a Tertiary extensional shear zone, Ruby Mountains-East Humbolt Range, Nevada: tectonic implications. Geology 19, 82-86.

Jelsma, H.A., Van Der Beek, P.A., Vinyu, M.L., 1993. Tectonic evolution of the Bindura-Shamva greenstone belt (northern Zimbabwe): progressive deformation around diapiric batholiths. Journal of Structural Geology 15, 163-176.

Jin, Y., McNutt, M.K., Zhu, Y., 1994. Evidence from gravity and topography data for folding of Tibet. Nature 371, 669-674.

Kohn, M.J., Spear, F., 2000. Retrograde net transfer reaction insurance for pressure-temperature estimates. Geology 28, 1127-1130.

Le Fort, P., 1975. Himalayas: the collided range. Present knowledge of the continental arc. American Journal of Science 275, 1-44.

Le Fort, P., 1986. Metamorphism and magmatism during the Himalayan. In: Coward, M.P., Ries, A.C. (Eds.), Collision Tectonics, Geological Society Special Publication, 19., pp. 159-172

Le Fort, P., Cuney, M., Deniel, C., France-Lanord, C., Sheppard, S.M.F.,
Upreti, B.N., Vidal, P., 1987. Crustal generation of the Himalayan leucogranites. Tectonophysics 134, 39-57.

Lee, J., 1995. Rapid uplift and rotation of mylonitic rocks from beneath a detachment fault: insights from potassium feldspar ${ }^{40} \mathrm{Ar} /{ }^{39} \mathrm{Ar}$ thermochronology, northern Snake Range, Nevada. Tectonics 14, 54-77.

Lee, J., Miller, E.L., Sutter, J.F., 1987. Ductile strain and metamorphism in an extensional tectonic setting: a case study from the northern Snake Range, Nevada, USA. In: Coward, M.P., Dewey, J.F., Hancock, P.L. (Eds.), Continental Extensional Tectonics, Geological Society Special Publication London, 28., pp. 267-298.

Lee, J., Dinklage, W.S., Hacker, B.R., Wang, Y., Gans, P.B., Calvert, A., Wan, J., Chen, W., Blythe, A., McClelland, W., 2000. Evolution of the Kangmar Dome, southern Tibet: structural, petrologic, and thermochronologic constraints. Tectonics 19, 872-896.

Lee, J., Wang, Y., McWilliams, M., Hourigan, J., Blythe, A., McClelland, W., 2002. Contraction, extension, and diapirism in Mabja Dome: implications for tectonics of southern Tibet. Geological Society of America Abstracts 34, 332.

Lee, J., McClelland, W., Wang, Y., McWilliams, M., Blythe, A., Hourigan, J., 2004. Oligocene-Miocene formation of middle crust in southern Tibet: geochronologic studies in Mabja Dome, in prep.

Lewis, C.J., Wernicke, B.P., Selverstone, J., Bartley, J.M., 1999. Deep burial of the footwall of the northern Snake Range decollement, Nevada. Geological Society America Bulletin 111, 39-51.

Makovsky, Y., Klemperer, S.L., Huang, L., Lu, D., 1996. Structural elements of the southern Tethyan Himalaya crust from wide-angle seismic data. Tectonics 15, 997-1005.

Maluski, H., Matte, P., Brunel, M., 1988. Argon 39-Argon 40 dating of metamorphic and plutonic events in the North and High Himalayas belts (southern Tibet-China). Tectonics 7, 299-326.

McGrew, A.J., Snee, L.W., 1994. ${ }^{40} \mathrm{Ar} /{ }^{39} \mathrm{Ar}$ thermochronologic constraints on the tectonothermal evolution of the northern East Humboldt Range metamorphic core complex, Nevada. Tectonophysics 238, 425-450.

Mercier, J.-L., Armijo, R., Tapponnier, P., Carey-Gailhardis, E., Lin, H.T., 1987. Change from late Tertiary compression to Quaternary extension in southern Tibet during the India-Asia collision. Tectonics 6, 275-304.

Miller, E.L., Gans, P.B., Garing, J.D., 1983. The Snake Range decollement: an exhumed mid-Tertiary ductile-brittle transition. Tectonics 2, 239-263.

Molnar, P., Tapponnier, P., 1975. Effects of a continental collision. Science $189,419-426$.

Nelson, K.D., Zhao, W., Brown, L.D., Kuo, J., Che, J., Liu, X., Klemperer, S.L., Makovsky, Y., Meissner, R., Mechie, J., Kind, R., Wenzel, F., Ni, J., Nabelek, J., Chen, L., Tan, H., Wei, W., Jones, A.G., Booker, J., Unsworth, M., Kidd, W.S.F., Hauck, M., Alsdorf, D., Ross, A., Cogan, M., Wu, C., Sandvol, E.A., Edwards, M., 1996. Partially molten middle crust beneath southern Tibet: synthesis of project INDEPTH results. Science 274, 1684-1688.

Nyman, M.W., Pattison, D.R.M., Ghent, E.D., 1995. Melt extraction during formation of K-feldspar + sillimanite migmatites, west of Revelstoke, British Columbia. Journal of Petrology 36, 351-372.

Powell, R., Holland, T.J.B., 1988. An internally consistent dataset with uncertainties and correlations: 3 . Applications to geobarometry, worked examples and a computer program. Journal of Metamorphic Geology 6, $173-204$.

Quidelleur, X., Grove, M., Lovera, O.M., Harrison, T.M., Yin, A., Ryerson, F.J., 1997. The thermal evolution and slip history of the Renbu Zedong thrust, southeastern Tibet. Journal of Geophysical Research 102, 2659-2679.

Ramberg, H., 1980. Diapirism and gravity collapse in the Scandinavian Caledonides. Journal Geological Society London 137, 261-270.

Ratschbacher, L., Frisch, W., Liu, G., Chen, C., 1994. Distributed deformation in southern and western Tibet during and after the India-Asia collision. Journal of Geophysical Research 99, 19,917-19, 945. 
Regional Geological Surveying Party, 1993. Regional Geology of Xizang (Tibet) Autonomous Region, Geological Publishing House.

Rey, P., 1993. Seismic and tectonometamorphic characters of the lower continental crust in Phanerozoic areas: a consequence of post thickening extension. Tectonics 12, 580-590.

Reynolds, S.J., Lister, G.S., 1990. Folding of mylonitic zones in Cordilleran metamorphic core complexes: evidence from near the mylonitic front. Geology 18, 216-219.

Royden, L.H., Burchfiel, B.C., 1987. Thin-skinned north-south extension within convergent Himalayan region: gravitational collapse of a Miocene topographic front. In: Coward, M.P., Dewey, J.F., Hancock, P.L. (Eds.), Continental Extensional Tectonics, Geological Society Special Publication, 28., pp. 611-619.

Scharer, U., Xu, R., Allegre, C., 1986. U-(Th)-Pb systematics and ages of Himalayan leucogranites, south Tibet. Earth Planetary Science Letters 77, 35-48.

Schwerdtner, W.M., Sutcliff, R.H., Troeng, B., 1978. Patterns of total strain in the crustal region of immature diapirs. Canadian Journal of Earth Sciences 15, 1437-1447.

Searle, M.P., 1983. Stratigraphy, structure and evolution of the TibetanTethys zone in Zanskar and the Indus suture zone in the Ladakh Himalaya. Transactions of the Royal Society of Edinburgh 73, $205-219$.

Searle, M.P., Cooper, D.J.W., Rex, A.J., 1988. Collision tectonics of the Ladakh Zanskar Himalaya. Philosophical Transactions of the Royal Society of London Series A 326, 117-150.

Searle, M., Corfield, R.I., Stephenson, B., McCarron, J., 1997. Structure of the north Indian continental margin in the Ladakh-Zanskar Himalayas: implications for the timing of obduction of the Spontang ophiolite, India-Asia collision and deformational events in the Himlaya. Geological Magazine 134, 297-316.

Spear, F., Menard, T., 1989. Program GIBBS: a generalized Gibbs method algorithm. American Mineralogist 74, 942-943.

van Staal, C.R., Williams, P.F., 1983. Evolution of a Svecofennian-mantled gneiss dome in SW Finland, with evidence for thrusting. Precambrian Research 21, 101-128.

Tapponnier, P., Peltzer, G., Le Dain, A.Y., Armijo, R., Cobbold, P., 1982. Propagating extrusion tectonics in Asia: new insights from simple experiments from plasticine. Geology 10, 611-615.

Teyssier, C., Whitney, D.L., 2002. Gneiss domes and orogeny. Geology 30, 1139-1142.

Thompson, A.B., England, P.C., 1984. Pressure-temperature-time paths of regional metamorphism II: their influence and interpretation using mineral assemblages in metamorphic rocks. Journal of Petrology 25, 929-955.

Van Den Eeckhout, B., Grocott, B., Vissers, R., 1986. On the role of diapirism in the segregation, ascent and final emplacement of granitoid magmas-discussion. Tectonophysics 127, 161-169.

Vannay, J.-C., Hodges, K.V., 1996. Tectonomorphic evolution of the Himalayan metamorphic core between the Annapurna and Dhaulagiri, central Nepal. Journal of Metamorphic Geology 14, 635-656.

Wernicke, B., 1985. Uniform-sense normal simple shear of the continental lithosphere. Canadian Journal of Earth Sciences 22, 108-125.

Yin, A., Harrison, T.M., Ryerson, F.J., Chen, W., Kidd, W.S.F., Copeland, P., 1994. Tertiary structural evolution of the Gangdese thrust system, southeastern Tibet. Journal of Geophysical Research 99, 18175-18201. 